\title{
Circular economy monitoring - how to make it apt for biological cycles?
}

\author{
Kranti Navare $^{1,2 *}$, Bart Muys ${ }^{3}$, Karl C. Vrancken ${ }^{2,4}$, Karel Van Acker $^{1,5}$ \\ ${ }^{1} \mathrm{KU}$ Leuven, Department of Materials Engineering, Kasteelpark Arenberg 44, Leuven 3001, Belgium \\ ${ }^{2} \mathrm{VITO}$, Sustainable materials, Boeretang 200, Mol 2400, Belgium \\ ${ }^{3} \mathrm{KU}$ Leuven, Division Forest, Nature and Landscape, Celestijnenlaan 200E-2411, BE-3001 Leuven, Belgium \\ ${ }^{4}$ University of Antwerp, Department of Bio-engineering, Groenenborgerlaan 171, 2020 Antwerp, Belgium \\ ${ }^{5} \mathrm{KU}$ Leuven, Research Centre for Economics and Corporate Sustainability, Warmoesberg 26, Brussels 1000 , \\ Belgium \\ *Corresponding author. E-mail contact: kranti.navare@kuleuven.be
}

\section{Highlights}

1. Existing circular economy (CE) monitors, mainly, assess the extent to which resources are looped back in the economy and seem less apt for assessing the circularity of biological cycles.

2. Characteristics of biological cycles, that distinguish them from technical cycles, are their renewability, potential use in cascading, closing the biological nutrient loop, and the environmental impact of biotic resources depletion, land-use and biogenic carbon flows.

3. These characteristics need to be added to CE monitoring criteria, to ensure the sustainable and circular use of natural resources.

\section{Abstract}

Circular economy (CE) principles distinguish between technical and biological cycles. Technical cycles involve the management of stocks of non-renewable abiotic resources that cannot be appropriately returned to the biosphere, whereas, biological cycles involve the flows of renewable biotic resources that can safely cycle in and out of the biosphere. Despite this distinction, existing CE monitors are typically developed for technical cycles, and focus mainly on the extent to which resources are looped back in the technosphere. These monitors seem less apt to assess the circularity of biological cycles. This study aims to identify this gap by critically reviewing the CE monitoring criteria and CE assessment tools, and evaluate if they include the four key characteristics of biological cycles.

Firstly, biotic resources, although renewable, require to be harvested sustainably. Secondly, while abiotic resources can be restored and recycled to their original quality, biotic resources degrade in quality with every subsequent use and are, hence, cascaded with every application. Thirdly, biotic resources should safely return as nutrients to the biosphere to support the regeneration of ecosystems. Fourthly, biological cycles have environmental impacts due to resource extraction, resulting from land-use and resource-depletion and biogenic carbon flows. The CE monitoring criteria lack in thoroughly assessing these characteristics. With the growing demand for biotic resources, the gap in the assessment could exacerbate the overexploitation of natural resources and cause the degradation of ecosystems. The study discusses measures to bridge this gap and suggests ways to design a CE assessment framework that is also apt for biological cycles.

\section{Keywords}

Bioeconomy, Circular economy indicators, Sustainable sourcing, Cascading, Biological nutrient cycling, Land-use impact, Resource depletion 


\begin{tabular}{|c|c|}
\hline Abiotic resources & $\begin{array}{l}\text { Abiotic resources are inorganic (such as metals or minerals), non-living matter } \\
\text { (such as fossil fuels) or synthetic material from non-living matter (such as fossil- } \\
\text { based plastic). These resources are non-renewable or finite by nature. }\end{array}$ \\
\hline Bio-based materials & Materials derived from biomass \\
\hline Bio-economy & $\begin{array}{l}\text { Economy pertaining to production of biotic resources and their conversion into } \\
\text { food, feed, biobased material and energy. }\end{array}$ \\
\hline Biocomposites & $\begin{array}{l}\text { Composites made of a mixture of plastic polymers and natural fibers, such as } \\
\text { wood (wood-plastic composites) or agricultural crops. }\end{array}$ \\
\hline Biodegradability & Refers to the capability of being degraded under the action of micro-organisms. \\
\hline Biological cycles & $\begin{array}{l}\text { Biological cycles, typically described by the left-hand side of Ellen MacArthur } \\
\text { (EMF) butterfly diagram, contain materials that can safely cycle in and out of } \\
\text { the biosphere (Ellen MacArthur Foundation, 2017). Hence, in this cycle, the } \\
\text { resources are harvested from ecosystems, cascaded through several material- } \\
\text { applications, and at the end of their product life decompose to re-enter } \\
\text { biosphere and restore the natural capital. } \\
\text { Although, it would be more appropriate to refer to it as 'biogeochemical cycle' } \\
\text { because on decomposition the materials cycle through both biotic (biosphere) } \\
\text { and abiotic (lithosphere, atmosphere, and hydrosphere) compartments of } \\
\text { earth. }\end{array}$ \\
\hline Biotic resources & $\begin{array}{l}\text { Biotics resources are living organic matter produced by the biological system } \\
\text { using atmospheric carbon and solar energy (e.g. wood, silk). These resources } \\
\text { are intrinsically renewable in nature. }\end{array}$ \\
\hline Biosphere & Part of the Earth and its atmosphere occupied by living organisms. \\
\hline Biopolymers & Polymers produced from living organisms. \\
\hline Dissipative losses & $\begin{array}{l}\text { The losses to the environment. The material that is unrecoverable, and thus for } \\
\text { which recycling is inherently not feasible. }\end{array}$ \\
\hline Material & $\begin{array}{l}\text { Material is a substance that constitutes an object. In this paper, the term } \\
\text { material is used synonymously with the term substance. }\end{array}$ \\
\hline Resource & $\begin{array}{l}\text { A 'resource' is considered as such when it has an intrinsic 'value' or 'utility' for } \\
\text { humans (Beylot et al., 2020), encompassing abiotic (fossils and minerals) and } \\
\text { biotic (biomass) resources. }\end{array}$ \\
\hline Resource quality & $\begin{array}{l}\text { The definition of resource quality has been derived from the definition } \\
\text { proposed by Sirkin and Houten (1994). It is the measure of potential resource } \\
\text { utility - the capacity to perform tasks of various degrees of difficulty. It is the } \\
\text { potential (re-)usability, recoverability and recyclability of the material. In this } \\
\text { paper, the term 'material-value' is used synonymously with 'resource-quality'. }\end{array}$ \\
\hline Technical cycles & $\begin{array}{l}\text { Technical cycles, typically described by the right-hand side of Ellen MacArthur } \\
\text { Foundation butterfly diagram, contain flows of materials that cannot be } \\
\text { appropriately returned to the biosphere (Ellen MacArthur Foundation, 2017, } \\
\text { 2015). Hence, technical cycles are designed to circulate resources in the } \\
\text { technosphere as long as possible, without entering the biosphere }\end{array}$ \\
\hline Technosphere & $\begin{array}{l}\text { Refers to the human system, i.e. the physical environment built or modified by } \\
\text { humans, which is a sub-system to the biosphere. }\end{array}$ \\
\hline
\end{tabular}




\section{Introduction}

Circular Economy (CE) is an approach to promote sustainable use of resources and address environmental challenges. CE has its conceptual roots in industrial ecology, which envisions a material symbiosis between different industries and production processes (Andersen, 2007). Industrial ecology emphasizes that these linkages enable the use of residual waste and by-products of one industry as a feedstock for other industries. This improves overall resource efficiency and hence reduces the use of virgin resources and emissions to the environment.

The CE principles distinguish between technical and biological cycles (Braungart et al., 2007; Ellen MacArthur Foundation, 2015). The distinction between these cycles is well illustrated in the CE 'butterfly diagram' by the Ellen MacArthur Foundation (Ellen MacArthur Foundation, 2015). Technical cycles involve managing non-renewable stocks of abiotic resources and the flows of materials that cannot be appropriately returned to the biosphere. Whereas, biological cycles contain the flows of renewable biotic resources that can safely cycle in and out of the biosphere. Abiotic resources are finite, and hence, technical cycles are designed such that the resources can be looped back in the technosphere for as long as possible. Once mined (in the case of inorganic materials) or produced (in the case of synthetic materials), their value is preserved as much as possible by prioritizing the socalled inner cycles (i.e. maintenance, reuse, repair), maximizing the number of consecutive cycles and increasing the time spent in each cycle (Ellen MacArthur Foundation, 2015). On the other hand, in biological cycles, the products are designed with the intention to be consumed or to be used in cascading and subsequently decompose to re-enter the biosphere (Bocken et al., 2016; Braungart et al., 2007). It should be acknowledged that the distinction between technical and biological cycles is not straightforward. In reality, biotic resources are mixed with abiotic resources to make products. Biotic resources are also used to make products that are not biodegradable, making them characteristic of technical cycles; most notable are the drop-in polymers such as bio-based polyethylene (European Environmental Agency, 2018). On the other hand, there are products of abiotic origin that are bio-degradable, such as fossil-based biodegradable polymer polybutylene adipate-co-terephthalate (PBAT), which is typical of material in biological cycles.

Having had its origins in industrial ecology, CE discussions and assessments today often have a narrow focus on technical cycles. Although the CE concepts have been extended to biological cycles, the CE assessment and monitoring seem insufficiently adapted to biological cycles (Haas et al., 2020; Leipold and Petit-Boix, 2018). A Google Scholar search for the term 'circular economy' combined with 'biological' or 'biobased' (in the title, keywords or abstract) delivers a total of only 25 results (Annex A). The majority of the articles center around (1) the design of products, supply-chain, bio-refineries and business models and (2) the conceptual distinction between technical and biological cycles. Concrete research on CE assessment criteria and monitoring specifically for biological cycles or inclusive of biological cycles seems to be lacking (Haas et al., 2020). In biological cycles, resources should be cascaded in the application and eventually returned to the biosphere to become valuable feedstock for a new cycle (Ellen MacArthur Foundation, 2015). However, most CE monitors mainly assess the extent to which resources are looped back in the economy; little attention has been paid to assessing the cascading use and the extent to which biotic resources at the end of their life decompose, release the nutrients to the biosphere and foster the regeneration of the ecological systems. Robust criteria or comprehensive indicators to quantify the fraction of biotic resources that sustainably close the nutrient cycle are still unavailable (Haas et al., 2020).

This could also be stemming from the popular notion that the use of biotic resources is circular and sustainable by its nature (Haas et al., 2020; Hetemäki et al., 2017). However, this assumption is not 
necessarily valid. There are several examples, in particular of bio-fuels (Fargione et al., 2008; Koh and Ghazoul, 2008; Searchinger et al., 2008), wherein shift to biomass has led to overexploitation of forest resources, land-use change, biodiversity loss and increased competition for land for food and feed. Hence, assessing the circularity of biological cycles and their impact on the ecosystem is essential.

Against this backdrop, this study aims to highlight the gaps in current CE monitoring in assessing the circularity of biological cycles and to identify the modifications required to adequately assess them. Identifying and acknowledging this gap is crucial and could then serve as a guideline for designing a thorough framework for assessing the progress towards the CE that is inclusive of biological cycles. This could potentially make way to more sustainable and circular use of natural resources and avoid further degradation of ecosystems.

\section{Methods and materials}

\subsection{Research design}

The methodology followed a series of steps, a graphical representation of which is in Fig. 1. The first step, to achieve the research objective, was to identify the criteria for assessing and monitoring CE (step 1 in Fig. 1), i.e. the criteria validating the progress towards CE. This was based on the definition of CE principles. However, there is no one agreed definition of CE. Thus, the CE definitions by themselves were not sufficient to derive the CE monitoring criteria. A study of CE practices, adopted by various stakeholders, was needed to deduce the guiding principles for CE implementation strategies (i.e. what should the CE strategies aim to achieve) and determine the widely accepted CE assessment criteria (i.e. what measures indicate the transition towards a $\mathrm{CE}$ ). This was done by studying the CE implementation strategies (Kalmykova et al., 2018) and the CE assessment criteria (Corona et al., 2019; Elia et al., 2017) identified by the CE review papers.

The second step was to identify the characteristics of biological cycles. This literature-based study started with the key sources Bocken et al. (2016), Ellen MacArthur Foundation(2017, 2010), European Environmental Agency (2018), Hetemäki et al. (2017). These sources provide guidelines for the design of the biological cycle to enable closing the biological nutrient loop. The search was then followed by a semi-structured snowballing literature study. The snowballing started with shortlisting the fundamental characteristics that distinguish biological cycles from technical cycles, based on the sources mentioned above. These characteristics were then studied in depth by a systematic review of literature from that specific field.

The third step was to evaluate if the CE monitoring criteria are sufficient to assess the characteristics of biological cycles. The study was further extended to analyze the current CE monitors - to study if they inherently assess the characteristics specific to the biological cycle (step 4). Step 3 and step 4 enable to highlight the gaps in current CE monitoring criteria and serve as a guideline for the adaptation required to make them inclusive of the biological cycle. 
STEP 1

STEP 3

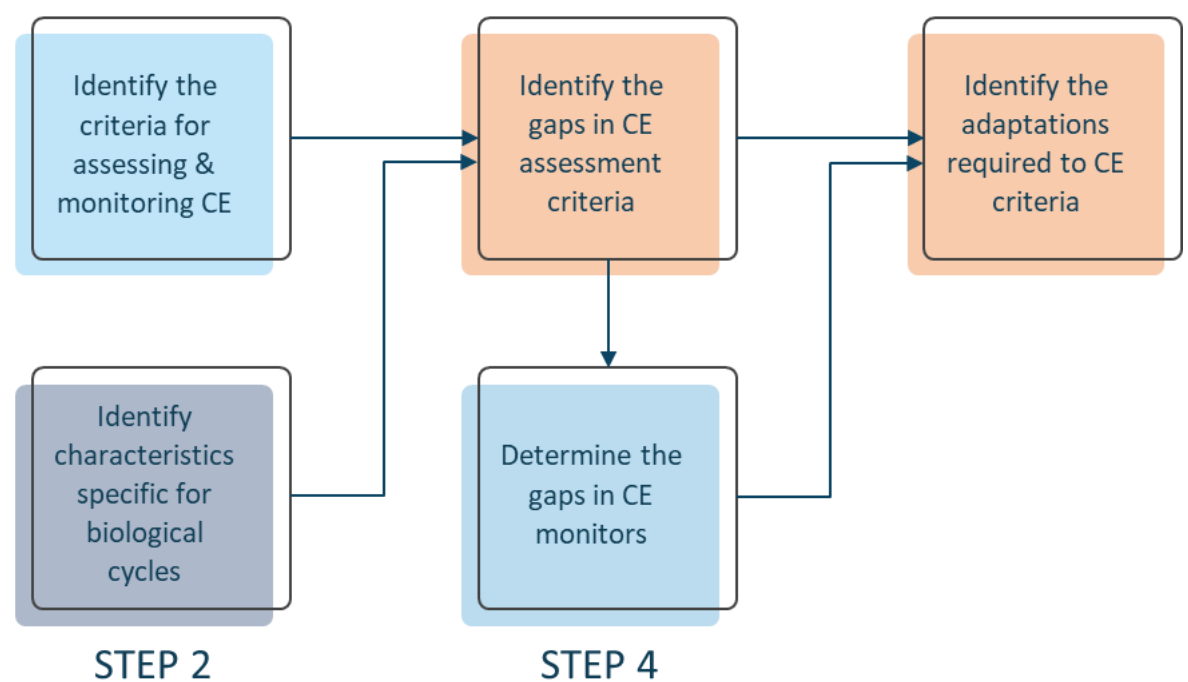

Figure 1: Research design - Illustration of steps followed to evaluate if (1) current criteria for CE monitoring are apt for assessing circularity of biological cycles (2) current CE monitors consider the characteristics of the biological cycle in the circularity assessment

\subsection{Reviewing existing CE monitors}

Numerous monitoring tools of circularity assessment - in the form of indicators, metrics, frameworks - have been developed in the last few years. The question relevant for this study is - how many of these CE monitors evaluate the criteria for circularity of biological cycles. Additionally, the CE monitors that evaluate those criteria do so to what extent.

Firstly, the current CE monitors were listed, which was done by a systematic literature review (Annex B provides the complete list of indicators studied). Here, a monitor is defined as a quantitative measure of progress towards achieving an objective. Consequently, the search included broad fields of quantitative assessments of CE, i.e. CE indices, indicators, metrics. The identification of CE metrics started with the search of the literature on the circular economy via Scopus and Google Scholar, using combinations of search words: 'circular economy', 'circularity', 'evaluation', 'assessment', 'measure', 'indicators', 'indices', 'index', and 'metrics' for the database search in title, abstract and keywords fields.

TITLE-ABS-KEY ( ("Circular economy" OR "Circularity") AND ("measure" OR "metric" OR "evaluation" $O R$ "assessment" OR "indicators" OR "indices" OR "index"))

In addition to the literature search, review papers on CE indicators were studied to ensure the completeness of the list (Corona et al., 2019; Moraga et al., 2019; Parchomenko et al., 2019; Rossi et al., 2020; Saidani et al., 2019). The most extensive list of CE indicators was published by Saidani et al. (2019), who reviewed 55 CE monitors. Some sources, mainly, Parchomenko et al. (2019) and Corona et al. (2019) consider even those indicators that are not specific to CE assessment but could potentially be useful for CE monitoring. These indicators were not included in this study, to maintain the focus only on CE monitors.

The analysis resulted in 59 sets of CE metrics, coming from 40 journal papers, 12 technical reports, and 7 websites. The search for CE monitors was kept broad to include the CE monitors at different levels of implementation (micro, meso and macro), in different sectors (construction, manufacturing etc.), and across different countries. The CE monitors specific to technical cycles were also included. 
Out of the 59 indicators, 23 indicators were developed for a specific industry or were demonstrated using a case study from a particular industry. Out of these, 21 were on material or industry of technical sectors. For example, Graedel et al. (2011) focus on the recycling rate for metals. Only two referred to a bio-based industry, which was the food sector. Despite being specific for technical cycles, these monitors were included to evaluate if the underlying criteria are relevant for biological cycles. Additionally, it also highlights the inequality in the number of CE monitors existing specifically for each cycle, with a clear weightage towards technical cycles.

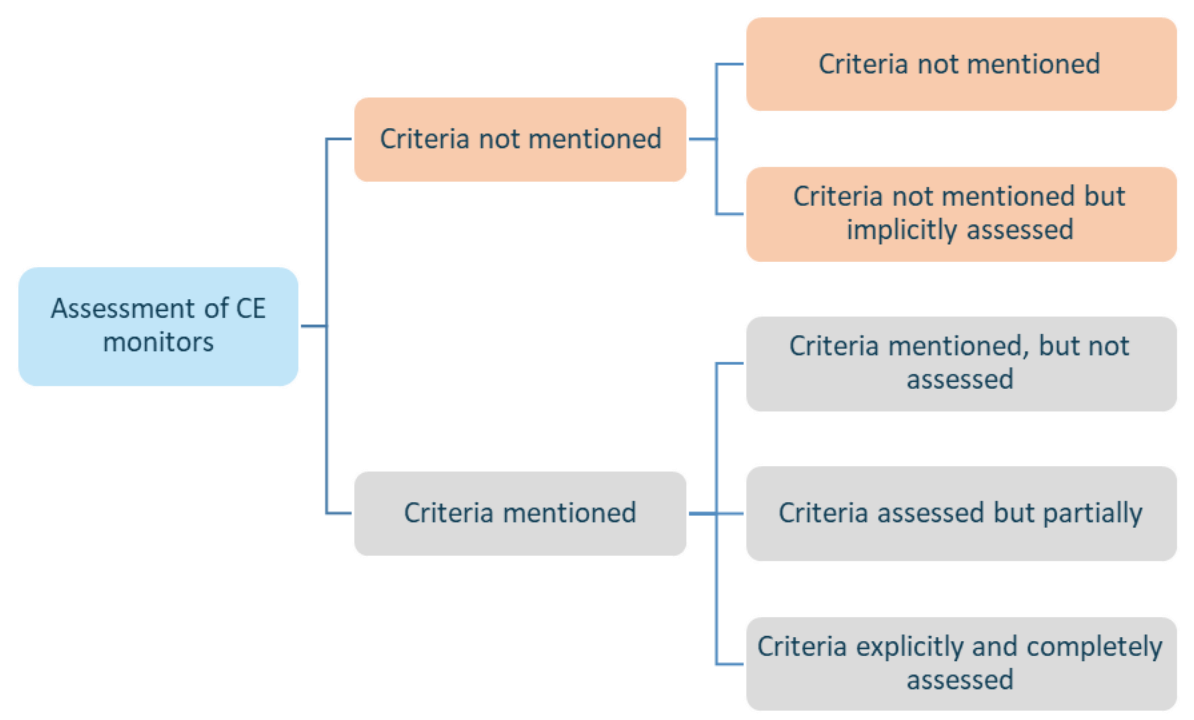

Figure 2: The framework for the evaluation of CE monitors - to validate if the CE monitors measure the parameters critical for assessing the circularity of biological cycles

CE monitors were then examined to validate whether each criterion relevant for biological cycles, as derived from the literature study, was considered. The framework for this evaluation is illustrated in Fig. 2. The first step was to examine whether there is a mention of the criterion. In case there is a mention, the second step was to determine whether the criterion is assessed and if assessed is it being assessed completely (marked in the results 'explicitly \& completely assessed') or only partially (marked as 'explicitly \& partially assessed'). Even in the case where there is no mention of the criterion, the next step was to determine whether it is assessed (marked as 'implicitly assessed'). There are cases where there is no mention of the criteria, but it is implicitly measured none the less. This framework accounts not only if the criteria are assessed but also to what extent are they being completely assessed.

\section{Results and Discussion}

\subsection{CE monitoring criteria specific for biological cycles}

The contours of CE are highly contested (Korhonen et al., 2018). The concept has been promoted by governments, academics and businesses (Kalmykova et al., 2018). However, there is no one agreed definition across these bodies. Several CE definitions exist. The most renowned definition has been framed by the Ellen MacArthur Foundation:

CE as an economy that is restorative and regenerative by design, and which aims to keep products, components and materials at their highest utility and value at all times, distinguishing between technical and biological cycles (Ellen MacArthur Foundation, 2010). 
A recent literature review by Kirchherr et al. (2017) found 114 CE definitions. Kirchherr et al. (2017) synthesized these definitions and proposed a uniting definition:

$C E$ is defined as "an economic system that replaces the 'end-of-life' concept with reducing, alternatively reusing, recycling and recovering materials in production/distribution and consumption processes. It operates at the micro-level (products, companies, consumers), mesolevel (eco-industrial parks) and macro-level (city, region, nation and beyond), with the aim to accomplish sustainable development, thus simultaneously creating environmental quality, economic prosperity and social equity, to the benefit of current and future generations".

This study uses these two definitions of the CE concept to deduce the guiding principles for CE practices and implementation strategies (i.e. the aspects CE strategies should strive to achieve). Since the study focused on the material circularity in technical and biological cycles, only the first sentence of the definition by Kirchherr et al. (2017) is considered. The analysis suggests that CE implementation strategies mainly aim at closing the material loop and fall into five main categories:

\section{Reducing the input of resources}

2. Minimizing the waste and losses produced

3. Increasing the input of recycled materials

4. Maximizing value, utility and durability of products

It has been assumed in this study that these requirements for CE strategies form the basis of the CE monitoring criteria, i.e. the measures that indicate the transition towards a CE.

Because of non-consensus over agreed definitions of $\mathrm{CE}$, the CE definitions themselves were insufficient to deduce the CE monitoring criteria. Hence, the list of CE monitoring criteria was complemented with the monitoring criteria identified by Corona et al. (2019) and Elia et al. (2017), who based their analysis on the CE strategies and practices. Elia et al. (2017) built on the results of the European Environmental Agency (2018) and added the criteria 'increasing share of renewable resources' and 'reducing emission levels' in addition to the above mentioned four criteria. Additionally, Corona et al. (2019) proposed to add three more criteria reflecting economic prosperity and social equity. Those are creating local jobs at all skill level, value-added creation and distribution and increase social wellbeing. To complete the list of CE assessment criteria, but yet maintain the focus on material circularity, the criteria - increasing share of renewable resources and reducing emission levels - have been included in this study. While the other three criteria, evaluating economic and social impact, have been considered out of scope for this study.

The question then arises whether these $\mathrm{CE}$ assessment criteria are adequate to evaluate the circularity of biological cycles. In answering that question, firstly, the characteristics of biological cycles in the context of CE were identified, in particular, those that are not assessed by existing CE monitoring criteria. These are:

1. Renewability, however, limited by its regeneration rate

2. Potential for cascading use of material

3. At the end-of-life, biodegrade and return to the biosphere to close the nutrient cycle

4. Environmental impact of biological cycles associated with resource extraction and biogenic carbon flows

These features have been discussed in-depth in the next sections. The aspects of biological cycles, assessed already by the existing CE monitoring criteria, are not included in the discussion. For example, 
the production or use phase of biological cycles also have an environmental impact but are not included, as it is assessed by an existing CE monitoring criterion (namely, reducing emission levels).

The next step was to evaluate if these characteristics are assessed by the CE monitoring criteria mentioned above. Each trait of the biological cycle is analyzed corresponding to the CE monitoring criteria to validate the extent to which they are aligned. The results of this analysis are described in sections 3.1.1.- 3.1.4 and summarized in section 3.1.5.

\subsubsection{Renewability}

Biotic resources are intrinsically renewable. Hence, the primary principle of CE 'to reduce the input of virgin resources' is less critical for these resources. This has been widely accepted, as can be seen with the growing emphasis on the bio-economy (European Commission, 2012; European Environmental Agency, 2018). The substitution of fossil-based resources by biotic resources is being encouraged. However, the renewability of these resources can only be ensured by sustainably producing and harvesting these resources (Hetemäki et al., 2017; Sikkema et al., 2017); by extracting resources at a rate lower than their regeneration capacity (Hilborn et al., 1995). In the forestry sector, this principle is termed 'sustained yield' (Muys et al., 2014). However, albeit essential, this is not sufficient to sustain the long-term productivity of the ecosystems. The harvesting or extraction processes could affect the ecosystem quality and capacity of biomass provisioning. Increasing agriculture and forestry productivity could lead to loss of species and landscape diversity, nutrient depletion or habitat loss (Muys et al., 2013). Some fishing techniques, e.g. dynamite fishing, trawling and dredging, could destroy habitat and deplete fish stock (Airoldi and Beck, 2007; Woods et al., 2016). These factors have an impact on the intrinsic capability of renewal and affect the long-term yield. The forestry sector has thus widened the concept of 'sustained yield' into a broader concept of 'sustainable yield', which aims at maintaining the ecosystem services and long-term productivity of forest ecosystems by safeguarding biodiversity and monitoring soil productivity (Muys et al., 2014). The fisheries sector defines the 'Maximum Sustainable Yield' (MSY) as the limit that can safely be removed from the fish stock while maintaining its capacity to produce sustainable yields in the long term (Maunder, 2008). The forestry and fisheries sectors have long histories of concern about sustainability. However, the CE discussions seem to be lagging in their consideration of sustainable exploitation of biotic resources (Hennig et al., 2016).

The growing need to reduce the dependency on fossil-based resources will see a shift towards biotic resources. A promising green alternative is lignin, one of the building blocks of biomass. It can substitute fossil-based resources in many sectors and products - fuels, resins, pharmaceuticals (Liao et al., 2020; Smolarski, 2012). The commercialization of lignin represents an opportunity to meet climate targets but could increase demand for biomass. Currently, lignin is abundantly available as residues in the paper and pulp industry and is used mainly for energy (Cline and Smith, 2017). But using lignin for material applications would mean finding alternative sources for energy supply, which could further increase the biomass demand.

The increasing demand for biomass may exacerbate the overexploitation of natural resources and cause further degradation of ecosystems (Ceccherini et al., 2020; European Environmental Agency, 2018; Hetemäki et al., 2017; Worm et al., 2006). The CE assessments should validate the renewability of the resources. The aim should be to minimize the use of biotic resources, along similar lines as abiotic resources. But, more importantly, ensure that it is within sustainable limits. In addition to validating that the extraction of biotic resources is below their natural regeneration rate, the $\mathrm{CE}$ monitors should also ensure that the ecosystem production capacity remains stable over-time. 


\subsubsection{Potential of cascading use of material}

Bio-based materials, i.e. materials derived from biomass, are biodegradable by nature, and it is harder to preserve the value of biodegradable materials (European Environmental Agency, 2018). Recycling these materials to their original form is difficult. They degrade in quality with each subsequent application (Jarre et al., 2020), resulting in lower structural properties and utility. This limits the applicability of the core CE principles - recycling and maximizing the utility - to biological cycles. The use of biotic resources is, thus, optimized by using it in cascades.

Cascading is the sequential use of resources as long, as many times and as efficiently as possible for material applications and only to recover energy from them when no other material application is feasible (Essel et al., 2008; Sirkin and Houten, 1994). The use of waste streams - post-consumer waste and industrial residual streams - for innovative products is encouraged. For example, wood, from construction and demolition waste, is used for particleboard production (Höglmeier et al., 2013; Merrild and Christensen, 2009). Inedible and unavoidable food waste and food residues are considered potential feedstocks for bioplastics, organic acid, essential oils (Teigiserova et al., 2019). Lignin, a by-product of pulp mills, is burned for low-grade energy. Better yet would be to use it for material applications, such as chemicals or pharmaceuticals (Smolarski, 2012), instead of being incinerated. Even after incineration or biodegradation, the emission capture and utilization technologies (Thomsen and Zhang, 2020) could extend the time these resources are in use. Cascading aims to maximize the value retrieved from the material over the multiple life-cycles. Value or materialquality here refers to the potential resource utility based on the inherent and intrinsic material properties, such as structural organization and chemical composition (Campbell-Johnston et al., 2020; Sirkin and Houten, 1994). The objective of maximizing the material-value is achieved by starting the use of resources for high-quality products, using the waste streams as much as possible, increasing the life-time of each application and hence overall life-time, and minimizing quality loss with each application (Brunet-Navarro et al., 2018; Fraanje, 1997; Keegan et al., 2013). These practices could enhance resource use efficiency, increase resource availability for other material uses, reduce dependency on virgin resources and reduce the environmental burden associated with resource use (Bais-Moleman et al., 2017; Fraanje, 1997; Höglmeier et al., 2015; Sikkema et al., 2013).

The majority of CE research has concentrated on material re-use and recycling. Little attention has been paid to assessing cascading. Assessing cascading would require considering the material-quality and rate of material-quality degradation along the material value chain (Haberl and Geissler, 2000), with a lower rate of quality loss signifying a more circular value-chain. The assessment should determine the highest value pathway for the material by assessing multiple-use phases and across multiple-material streams (i.e. virgin feedstock, waste and residues) and prioritize the use of materials for the highest quality application possible (Campbell-Johnston et al., 2020; Fraanje, 1999; Sirkin and Houten, 1994). High-quality material should not be allocated to low-quality applications. An integrated assessment of cascading - considering quality degradation over multiple-use phases and multiple streams - is generally lacking in CE monitoring and is essential to extract the maximum potential of the biological cycle.

The cascading principles have primarily belonged to the biomass domain (Kalverkamp et al., 2017) because, unlike metals and minerals, bio-based materials cannot be recycled to their original form. Natural fibers in bio-based material degrade in structural properties during the recycling process. However, the materials from abiotic resources also face quality degradation during the recycling processes, although the mechanisms might differ. Metals degrade in quality during recycling because they get mixed with undesirable elements or lower grade materials, resulting in lower-quality recycled material, i.e. material with lower inherent properties such as lower mechanical properties (Koffler and 
Florin, 2013). This has been referred to as downcycling in CE discussions, which is recycling that results in products or materials of lower value. Yet, CE assessment has paid limited attention to considering material value (Campbell-Johnston et al., 2020), which merely necessitates its assessments for both technical and biological cycles.

\subsubsection{Closing the biological nutrient cycle: biodegrade and return to the biosphere}

Bio-based materials are typically biodegradable and support the regeneration of the ecosystem after their decomposition. Hence, the core principle of $\mathrm{CE}$, i.e. reduce waste and increase recycling, seems essential but not sufficient for biological cycles. Additionally, ensuring 'closure of the biological nutrient cycle' is fundamental. It is essential to validate whether the biotic resources after decomposition feed the regeneration of the ecological systems.

Firstly, bio-based products are not necessarily biodegradable. A clear example of this is bio-based polymers (such as bio-polypropylene and bio-polyethylene; Bocken et al., 2016). These are typical drop-in bio-based polymers. They have the same structure as their fossil counterparts and hence are not biodegradable (Shogren et al., 2019). Additionally, mixing biotic resources with abiotic resources, a frequently-used method for enhancing the material properties of products, can hamper the biodegradability of the biotic resources. For example, bio-composites may not necessarily be biodegradable (Jiang et al., 2020). The aim of CE should be to enhance the separability of the material of biotic and abiotic origin, to enhance the biodegradability of bio-based materials. When materials from biotic and abiotic sources cannot be separated or when the bio-based materials are nonbiodegradable, they should be treated as part of technical cycles, focusing on enhancing their reusability and recyclability.

Bio-based alternatives to fossil-based products face several challenges even when biodegradable. For instance, bio-based plastic polylactic acid (PLA), which is biodegradable but has an appearance similar to that of fossil-based alternative (polyethylene terephthalate PET). Hence, these two fractions get collected together in the waste streams, posing two problems. Firstly, the biodegradable fraction should be composted (after cascading uses if possible). Mixing the two streams increases the difficulty of eventually composting this fraction. Secondly, the presence of PLA seriously hinders the existing recycling process of PET (Alaerts et al., 2018). Hence, bio-based materials or products should be collected separately - for recycling or composting purposes. Separation of bio-based materials or products from their abiotic counterparts is crucial for the closure of both technical and biological cycles.

Yet another challenge is the dissipative losses, i.e. the losses to the environment that are not recoverable. The products that result in dissipative losses during use (such as lubricants, tires or paint) should be made compatible with biological systems (Bocken et al., 2016; Braungart et al., 2007). They should degrade and not accumulate in nature. However, this not always the case. The emissions to the environment contain non-biodegradable materials, also of abiotic origin. They gradually accumulate in the biosphere over-time and interfere with the ecosystem functioning (Thomsen et al., 2012). If toxic in nature, it could severely impact plant, animal or human health. For instance, industrial emissions contain toxic pollutants that spread on agricultural land and are becoming part of foodsystems (Marini et al., 2021; Pizzol et al., 2010). Hence, the presence of non-biodegradable or abiotic resources in dissipative emissions should be avoided. Secondly, if unavoidable, the toxicity and impact on ecosystem functioning as a result of their occurrence should be minimized. Moreover, even if they were biodegradable, whether these resources are feedstock for the regeneration of the ecosystems is less known. 
Non-hazardous biodegradable bio-based materials that do safely decompose are assumed to return as nutrients to the biosphere. However, these nutrients do not necessarily feed the regeneration of the ecosystem. Nutrients are extracted from the biosphere as harvested food, energy and material, and are discharged back into the biosphere when it decomposes. The nutrients not returned to the place or at a rate at which ecosystems absorb the nutrients can disrupt the nutrient cycles (Skene, 2018). Without adequate measures to ensure nutrient cycling, shortages are created at the source of biomass, and nutrient excess in the ecosystems where the biomass is consumed or discharged (De Oliveira Garcia et al., 2018; European Environmental Agency, 2018). This is especially true in the case of agricultural systems where the urban areas are becoming concentrators of nutrients (Chowdhury et al., 2014; Kalmykova et al., 2012; Papangelou et al., 2020) and the rural soils are degrading and relying increasingly on synthetic fertilizers (Lathuillière et al., 2014). This disruption of the nutrient system is damaging at both places (Battye et al., 2017). It causes environmental issues like eutrophication (Chowdhury et al., 2014; Lassaletta et al., 2014), where the nutrients are concentrated and discharged into waste streams. At the sites where nutrients are extracted, the soil fertility is reduced; increasing the dependency on synthetic fertilizers. Excessive use of fertilizer, causing fertilizer run-off from the agricultural system to water-bodies, can also lead to increased toxicity levels and further reduce the capacity of soil to support growth (Coppens et al., 2016; Dalin and RodríguezIturbe, 2016; Lassaletta et al., 2014; Smil, 2011). Modern agricultural practices, such as excessive tillage and the use of heavy machinery, accelerate this process by increasing erosion and water runoff, carrying nutrients out of the soil and into water systems. Other than the farming practices, megatrends such as globalization, international trade (Dalin and Rodríguez-Iturbe, 2016; Lassaletta et al., 2014; Schipanski and Bennett, 2012), and urbanization further contribute to the relocation of nutrients and disruption of nutrient balance (Ellen MacArthur Foundation, 2017).

These nutrient imbalances have a severe impact on human and ecosystem functioning. The Stockholm Resilience Center has highlighted that the biogeochemical nutrient cycle (of nitrogen and phosphorus) is one of the planetary boundaries that has already been transgressed. There is sufficient evidence to say that this has been, radically, caused by human industrial and agricultural processes (Steffen et al., 2015). Hence, an assessment of a system's capability to close the biological nutrient cycle and maintain the ecosystem's regenerative capacity is crucial and essential.

To summarize, CE concepts assume that the biomass that decomposes and returns to the biosphere contributes to closing the biological nutrients loop (Haas et al., 2020). However, it is evident that this is not always true. Hence, the CE monitors should assess the following aspect - Firstly, the biodegradability of bio-based materials; secondly, the occurrence and toxicity of hazardous substances in the emissions to the environment as a result of biodegradation; and thirdly, validate if the place and rate of decomposition of the material sustain the regeneration of ecosystems (Reijnders, 2008; Skene, 2018). This assessment should also include the biodegradable material of abiotic origin, while the non-biodegradable bio-based materials should be in the CE monitoring of technical cycles.

\subsubsection{Environmental impact specific to biological cycles}

Primary sectors producing biotic resources - agriculture, forestry and fisheries - have substantial impacts on the environment. The biotic resource use impacts the quantity and quality of ecosystems, natural capital (soil, water and air), biodiversity and landscape amenity value. The planetary boundaries developed by Stockholm Resilience Center point out that impact on five out of nine have a direct link to the bio-based economy: biogeochemical (nitrogen and phosphorus) cycle balance, land system change, freshwater consumption and the global hydrological cycle, loss of biosphere integrity (biodiversity loss and extinctions) and climate change (Steffen et al., 2015). Hence, biological cycles should not be inherently assumed to be environmentally friendly. 
The biotic resource use damages the environment, mainly, through the local ecosystem impact of resource extraction, resulting from resource depletion and land-use or ocean use interventions, and global climate impact of carbon emissions.

The biotic resource extraction impacts the capacity and quality of ecosystem functioning due to resource depletion. This is not the case with abiotic resource extraction, for which the impact occurs due to resource extraction and not due to depletion or scarcity. Abiotic resource depletion could impact resource availability for the future generation but does not affect the ecosystem health or functioning (Heijungs et al., 1997). Overexploitation of biotic resources could lead to a reduction or extinction of species, challenging their future availability. But more importantly, it causes indirect biodiversity loss (Crenna et al., 2018), for example, through trophic interactions (Chapin et al., 2000). Both direct and indirect biodiversity loss diminishes the total biomass available for ecosystem functioning, which could impact the ecosystem health, affecting the production capacity of the ecosystem (i.e. provisioning of resources) as well as other life-supporting functions (e.g. climate regulation, flood control). An example of this is the potential threat to coastal water quality and ecosystem stability due to the overexploitation of marine resources; by altering food web structures and reducing the population of non-target species (Woods et al., 2016; Worm et al., 2006). The resource depletion is an impact category relevant for extraction of non-cultivated biotic resources from the natural environment, e.g. hunting in the wild, timber from natural forest, fishing from oceans; and not for cultivation, i.e. harvesting from farms and plantations, for which the impacts are mainly due to land-use or ocean-use (Heijungs et al., 1997).

The impacts originating from land-use interventions are of two types - land occupation and land transformation. Land occupation is the continuous use of land for a specified land-use type for a certain period. Land transformation is modifying land to suit it for the intended use. Such as converting forest to agricultural land, draining land to establish arable fields, intensifying farmland production (Koellner et al., 2013). These interventions degrade ecosystem services due to a decline in vegetation, biodiversity, soil- and water quality (Foley et al., 2005; Saad et al., 2013; UNEP, 2019). The oceanbased activities damage the marine ecosystems, through habitat destruction (from fishing techniques, disturbances - dynamite fishing, fishery bottom trawling and dredging) and biodiversity loss (from habitat loss, by-catches; Kaiser et al., 2002; Woods et al., 2016). So far, concern about the impact of biotic resources extraction on ecosystem services has been limited in CE assessment. However, to ensure sustainable use of natural resources and to avoid burden shifting by moving from fossil-based to biotic resources, the impact of biotic resources extraction on ecosystem health, resulting from direct and indirect land-use impacts and resource depletion, needs to be accounted.

Another aspect unique to biological cycles is the climate impact of biogenic carbon. Biological cycle carbon management differs from that of the technical cycle in a way that carbon is both sequestered from and emitted to the biosphere in biological cycles. Carbon dioxide is absorbed from the atmosphere through photosynthesis and stored in biomass, and further on, in bio-based products. $\mathrm{CO}_{2}$ is emitted to the atmosphere when the biomass is incinerated or decomposes. The emissions balance out the initial carbon sequestration. The carbon storage in the bio-based products, even if temporary, contributes to delaying the emissions. Hence, carbon emissions from biogenic sources are often assumed to be 'carbon neutral'. Wood products have officially been accounted for as carbon sinks under the Kyoto Protocol (UNFCCC, 2012), and the use of bio-based products is seen as a climate mitigation strategy. However, the 'climate neutrality' assumption holds if the rate of carbon emission is lower than sequestration. Harvesting a tree that grows over several years and using it for bio-energy could create a 'carbon debt'. So, the biotic resources should be harvested at a rate below the rate of sequestration. Their use in long-lasting products and in cascading enhances their climate mitigation 
potential. Validating 'carbon neutrality' by evaluating time-explicit account of carbon flux - i.e. not only net carbon emission, but more importantly considering the rate of carbon sequestration, time over which carbon is stored and the rate of release of biogenic carbon - is essential to conclude the climate benefits of biological cycles.

The biological cycles also have an environmental impact in other phases of the product life-cycle, i.e. production, use and end-of-life. However, these impacts are not specific to biological cycles and also occur in technical cycles. They are not discussed in this study as the criteria to reduce the environmental impact associated with these phases is already included in the existing CE monitoring frameworks. The aim was to identify the additional criteria required to assess biological cycles.

\subsubsection{Summary}

Table 1 summarizes the results of this evaluation. Each of the characteristics of the biological cycle (mentioned in the column header of Table 1 ) is reviewed and compared to the CE monitoring criteria (listed in the row headers) to showcase the extent to which they are aligned. The contradictions between the two or the aspects where CE monitoring criteria fall short of including the biological cycle (highlighted in bold) lay the ground for the adaptations required to these criteria to integrate biological cycles in the current CE assessments.

Table 1: Summary of the evaluation of the characteristics of the biological cycle and comparing them with the CE monitoring criteria to validate the extent to which they are aligned (the gaps are highlighted in bold)

\begin{tabular}{|c|c|c|c|c|}
\hline $\begin{array}{l}\text { Biological cycles' } \\
\text { characteristics } \\
\text { CE } \\
\text { monitoring } \\
\text { criteria }\end{array}$ & Renewability & $\begin{array}{l}\text { Cascading use of } \\
\text { material }\end{array}$ & $\begin{array}{l}\text { Closing of the } \\
\text { biological nutrient } \\
\text { cycle }\end{array}$ & $\begin{array}{l}\text { Environmental } \\
\text { impact }\end{array}$ \\
\hline $\begin{array}{l}\text { Reducing input of } \\
\text { resources }\end{array}$ & $\begin{array}{l}\text { Important but not } \\
\text { sufficient. Essential } \\
\text { that resources are } \\
\text { sustainably sourced }\end{array}$ & & & \\
\hline Reducing waste & & & $\begin{array}{l}\text { More } \\
\text { importantly, the } \\
\text { need to validate } \\
\text { biodegradability, } \\
\text { presence of } \\
\text { hazardous } \\
\text { substances \& if } \\
\text { decomposition } \\
\text { sustains } \\
\text { regeneration }\end{array}$ & \\
\hline $\begin{array}{l}\text { Increasing } \\
\text { recycled resource }\end{array}$ & & $\begin{array}{l}\text { Additionally, } \\
\text { should optimize } \\
\text { the cascading use } \\
\text { of material }\end{array}$ & & \\
\hline $\begin{array}{l}\text { Increasing the use } \\
\text { of renewable } \\
\text { resources }\end{array}$ & $\begin{array}{l}\text { In contradiction with } \\
\text { the criteria to reduce } \\
\text { input. Validating if } \\
\text { resources are } \\
\text { sustainably sourced } \\
\text { becomes more } \\
\text { crucial }\end{array}$ & & & \\
\hline $\begin{array}{l}\text { Reducing } \\
\text { emissions (GHG) }\end{array}$ & & & & $\begin{array}{l}\text { In addition to the } \\
\text { environmental }\end{array}$ \\
\hline
\end{tabular}




\begin{tabular}{|l|l|l|l|l|}
\hline & & & & $\begin{array}{l}\text { impact associated } \\
\text { emissions, it is crucial } \\
\text { to assess impacts of } \\
\text { resource extraction } \\
\text { and assess the } \\
\text { temporal aspect of } \\
\text { emission }\end{array}$ \\
\hline $\begin{array}{l}\text { Maximizing value, } \\
\text { utility \& time in } \\
\text { use }\end{array}$ & & $\begin{array}{l}\text { Additionally, } \\
\text { should assess the } \\
\text { quality } \\
\text { degradation over } \\
\text { multiple-uses }\end{array}$ & \\
\hline
\end{tabular}

It is evident that current CE monitoring criteria fall short of assessing the key characteristics of biological cycles. Based on the gaps highlighted in Table 1, it can be suggested that CE monitoring should include, along with criteria applicable to technical cycles, the following criteria for accurately gauging transition towards circular biological cycles:

1. To ensure 'renewability of biotic resources', the additional CE assessment criterion should be increasing the use of sustainably-sourced resources

2. To optimize the 'cascading use of biotic resources', the criterion should be maximizing the value by identifying the best utilization pathway considering multiple-uses and multiple streams

3. To 'close the nutrient cycle', the criteria should be to ensure that

1. Enhancing separability and biodegradability of bio-based biological materials

2. Reducing the presence of hazardous substances in the emissions to the environment

3. Increasing the return of nutrients, in place and at a rate, that sustains the regeneration of the ecosystem

4. To minimize the 'environmental impact', the criterion for CE monitoring should be to assess the impacts of biotic resource extraction on ecosystem services, in particular, that resulting from land-use interventions and resource depletion and global climate impact of carbon balance, by accounting carbon sequestration, storage and release of biogenic carbon

\subsection{Gaps in existing CE monitors}

The existing CE monitors were evaluated to determine whether they assess the circularity criteria relevant to biological cycles. The study reviewed $59 \mathrm{CE}$ monitors - the summary of the results is provided in Table 2 and Figure 3. Annex B provides the complete list of CE monitors and evaluation results for each monitor, while Table 2 in the shortlist of only those monitors that assess at least one of the criteria. 
Sustainable harvesting

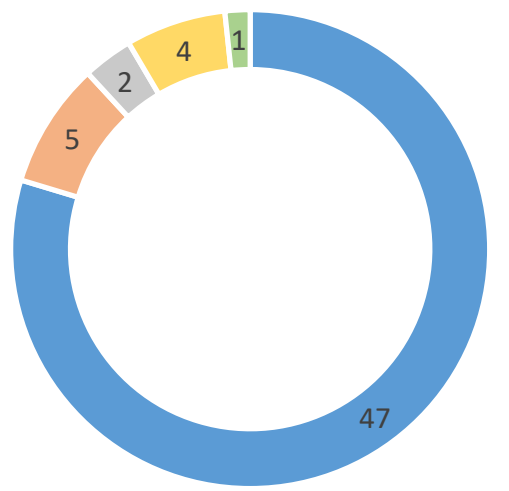

Closing biological nutrient loop

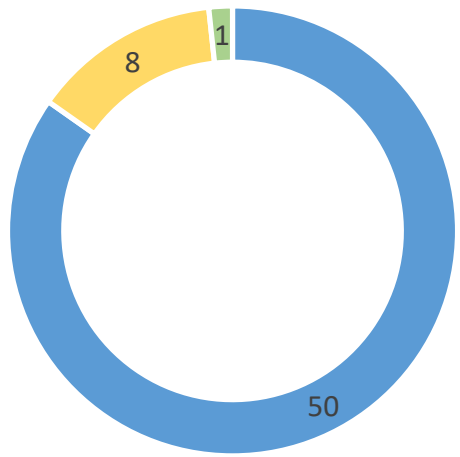

Cascading use

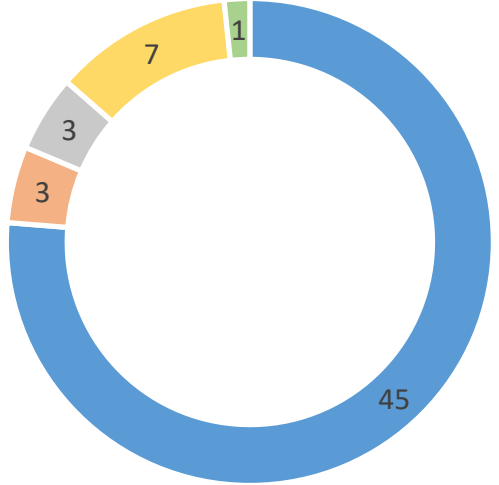

Environmental impact

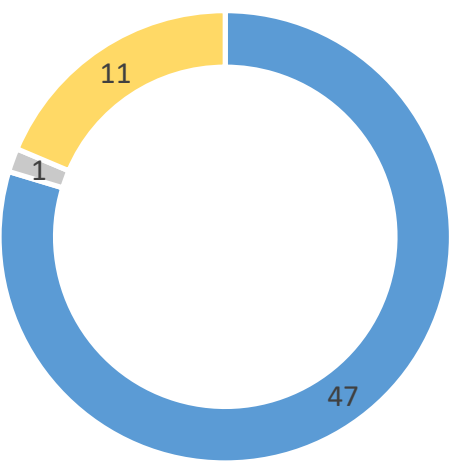

Mentioned but not assessed

implicitly assessed

Explicitly \& completly

assessed

assessd

Figure 3: Results of the CE monitors evaluation 
Table 2: Summary of the evaluation of CE monitors - validation if the CE monitors consider the criteria specific for circularity of biological cycle. This table includes only those CE monitors that consider at least one of the criteria. Empty cell represent that the criteria is '(not mentioned \&) not assessed'

\begin{tabular}{|c|c|c|c|c|c|}
\hline CE monitor & Source & Sustainable sourcing & Cascading use & $\begin{array}{l}\text { Closing the biological } \\
\text { nutrient cycle }\end{array}$ & $\begin{array}{l}\text { Environmental impact } \\
\text { specific to biological } \\
\text { cycles }\end{array}$ \\
\hline $\begin{array}{l}\text { Assessing circular trade- } \\
\text { offs }\end{array}$ & $\begin{array}{l}\text { Circle economy, } \\
\text { Camacho-Otero and } \\
\text { Ordoñez, } 2017\end{array}$ & $\begin{array}{l}\text { Explicitly but partially } \\
\text { assessed } \\
\text { Including criticality } \\
\text { (using resource price) } \\
\text { and renewability }\end{array}$ & $\begin{array}{l}\text { Mentioned (but not } \\
\text { assessed) }\end{array}$ & $\begin{array}{l}\text { Explicitly but partially } \\
\text { assessed Assess share of } \\
\text { material biodegradable }\end{array}$ & $\begin{array}{l}\text { Explicitly but partially } \\
\text { assessed } \\
\text { (The aspects assessed } \\
\text { are not known) }\end{array}$ \\
\hline $\begin{array}{l}\text { Value-based resource } \\
\text { efficiency }\end{array}$ & Di Maio et al., 2017 & $\begin{array}{l}\text { Implicitly assessed } \\
\text { Considered economic } \\
\text { value of stressed } \\
\text { resources }\end{array}$ & & & \\
\hline $\begin{array}{l}\text { Product-level-circularity- } \\
\text { metric }\end{array}$ & Linder et al., 2017 & $\begin{array}{l}\text { Implicitly assessed } \\
\text { Include the cost of } \\
\text { recirculated resources }\end{array}$ & $\begin{array}{l}\text { Implicitly assessed } \\
\text { Include the cost of } \\
\text { recirculated resources }\end{array}$ & & \\
\hline Hybrid LCA Model & Genovese et al., 2017 & $\begin{array}{l}\text { Implicitly assessed } \\
\text { LCA includes land-use } \\
\text { change and resource } \\
\text { scarcity }\end{array}$ & & & $\begin{array}{l}\text { Explicitly but partially } \\
\text { assessed, using LCA, } \\
\text { which is a methodology } \\
\text { to study environmental } \\
\text { impact. However, impact } \\
\text { on resource depletion on } \\
\text { ecosystem services and } \\
\text { time-dependent carbon } \\
\text { flows is rarely studied }\end{array}$ \\
\hline $\begin{array}{l}\text { Integrative Evaluation on } \\
\text { the Development of CE }\end{array}$ & Qing et al., 2011 & $\begin{array}{l}\text { Implicitly assessed } \\
\text { Includes per capita } \\
\text { green area }\end{array}$ & & & \\
\hline Eco-efficiency index & Laso et al., 2018 & $\begin{array}{l}\text { Implicitly assessed } \\
\text { Include the cost of raw } \\
\text { material }\end{array}$ & & & \\
\hline $\begin{array}{l}\text { Circular economy } \\
\text { toolbox }\end{array}$ & $\begin{array}{l}\text { "Measuring Circular } \\
\text { Economy | U.S. Chamber of } \\
\text { Commerce Foundation," } \\
\text { n.d. }\end{array}$ & $\begin{array}{l}\text { Explicitly but partially } \\
\text { assessed }\end{array}$ & $\begin{array}{l}\text { Explicitly but partially } \\
\text { assessed }\end{array}$ & $\begin{array}{l}\text { Explicitly but partially } \\
\text { assessed Assess share of } \\
\text { material biodegradable }\end{array}$ & \\
\hline
\end{tabular}




\begin{tabular}{|c|c|c|c|c|c|}
\hline CE monitor & Source & Sustainable sourcing & Cascading use & $\begin{array}{l}\text { Closing the biological } \\
\text { nutrient cycle }\end{array}$ & $\begin{array}{l}\text { Environmental impact } \\
\text { specific to biological } \\
\text { cycles }\end{array}$ \\
\hline & & $\begin{array}{l}\text { Includes share of } \\
\text { resources from certified } \\
\text { sources }\end{array}$ & $\begin{array}{l}\text { Assess closed-loop and } \\
\text { open-loop recycling } \\
\text { rates }\end{array}$ & & \\
\hline $\begin{array}{l}\text { Resource productivity } \\
\text { indicator }\end{array}$ & Wen and Meng, 2015 & & $\begin{array}{l}\text { Implicitly assessed } \\
\text { Include industrial added } \\
\text { value per unit material } \\
\text { input }\end{array}$ & & \\
\hline $\begin{array}{l}\text { Resource duration } \\
\text { indicator }\end{array}$ & $\begin{array}{l}\text { Figge et al., 2018; Franklin- } \\
\text { Johnson et al., } 2016\end{array}$ & & $\begin{array}{l}\text { Implicitly assessed } \\
\text { Include time in use of a } \\
\text { resource }\end{array}$ & & \\
\hline $\begin{array}{l}\text { Indicators for Material } \\
\text { input for CE }\end{array}$ & $\begin{array}{l}\text { European Environment } \\
\text { Agency EEA, } 2016\end{array}$ & $\begin{array}{l}\text { Mentioned (but not } \\
\text { assessed) }\end{array}$ & $\begin{array}{l}\text { Mentioned (but not } \\
\text { assessed) }\end{array}$ & & $\begin{array}{l}\text { Mentioned (but not } \\
\text { assessed) }\end{array}$ \\
\hline $\begin{array}{l}\text { Material circularity } \\
\text { indicator }\end{array}$ & $\begin{array}{l}\text { Ellen MacArthur } \\
\text { Foundation, } 2015\end{array}$ & $\begin{array}{l}\text { Mentioned (but not } \\
\text { assessed) } \\
\text { Suggests use of } \\
\text { complementary risk } \\
\text { indicator 'material } \\
\text { scarcity' }\end{array}$ & & & \\
\hline $\begin{array}{l}\text { Product circularity } \\
\text { indicators }\end{array}$ & Bracquené et al., 2019 & & $\begin{array}{l}\text { Mentioned (but not } \\
\text { assessed) }\end{array}$ & & \\
\hline $\begin{array}{l}\text { Recycling and collection } \\
\text { rates }\end{array}$ & Haupt et al., 2017 & & $\begin{array}{l}\text { Explicitly but partially } \\
\text { assessed } \\
\text { Assess closed-loop and } \\
\text { open-loop recycling } \\
\text { rates }\end{array}$ & & \\
\hline $\begin{array}{l}\text { End-of-life Recycling } \\
\text { rates }\end{array}$ & Graedel et al., 2011 & & $\begin{array}{l}\text { Explicitly but partially } \\
\text { assessed } \\
\text { Assess functional and } \\
\text { non-functional recycling } \\
\text { rates }\end{array}$ & & \\
\hline Circularity index & Cullen, 2017 & & $\begin{array}{l}\text { Explicitly but partially } \\
\text { assessed }\end{array}$ & & \\
\hline
\end{tabular}




\begin{tabular}{|c|c|c|c|c|c|}
\hline CE monitor & Source & Sustainable sourcing & Cascading use & $\begin{array}{l}\text { Closing the biological } \\
\text { nutrient cycle }\end{array}$ & $\begin{array}{l}\text { Environmental impact } \\
\text { specific to biological } \\
\text { cycles }\end{array}$ \\
\hline & & & $\begin{array}{l}\text { Assess the energy } \\
\text { required for material \& } \\
\text { virgin material }\end{array}$ & & \\
\hline Circular economy index & Di Maio et al., 2015 & & $\begin{array}{l}\text { Explicitly but partially } \\
\text { assessed } \\
\text { Assess market value }\end{array}$ & & \\
\hline Material recycling index & Reuter and Van Schaik, 2016 & & $\begin{array}{l}\text { Explicitly but partially } \\
\text { assessed } \\
\text { Assess recyclate } \\
\text { composition }\end{array}$ & & \\
\hline Circular economy toolkit & Evans and Bocken, 2014 & & & $\begin{array}{l}\text { Explicitly but partially } \\
\text { assessed } \\
\text { Assess share of material } \\
\text { biodegradable }\end{array}$ & \\
\hline Circular pathfinder & $\begin{array}{l}\text { https://rescomd58.eurostep } \\
\text {.com/idealco/pathfinder }\end{array}$ & & & $\begin{array}{l}\text { Explicitly but partially } \\
\text { assessed Assess share of } \\
\text { material biodegradable }\end{array}$ & \\
\hline $\begin{array}{l}\text { Input-output balance } \\
\text { sheet }\end{array}$ & $\begin{array}{l}\text { https://www.capcon.it/en/ } \\
\text { measure-the-circularity-of- } \\
\text { a-product/ }\end{array}$ & & & $\begin{array}{l}\text { Explicitly but partially } \\
\text { assessed Assess share of } \\
\text { material biodegradable }\end{array}$ & \\
\hline $\begin{array}{l}\text { Circular Economy } \\
\text { Monitoring Framework }\end{array}$ & $\begin{array}{l}\text { https://ec.europa.eu/eurost } \\
\text { at/web/circular- } \\
\text { economy/indicators/monito } \\
\text { ring-framework }\end{array}$ & & & $\begin{array}{l}\text { Explicitly but partially } \\
\text { assessed Assess share of } \\
\text { material biodegradable }\end{array}$ & \\
\hline $\begin{array}{l}\text { EU Resource efficiency } \\
\text { scoreboard }\end{array}$ & $\begin{array}{l}\text { European Commission, } \\
\text { 2015b }\end{array}$ & & & $\begin{array}{l}\text { Explicitly but partially } \\
\text { assessed Assess area } \\
\text { under organic farming, } \\
\text { soil erosion, nutrient } \\
\text { balance }\end{array}$ & $\begin{array}{l}\text { Explicitly but partially } \\
\text { assessed } \\
\text { Assess greenhouse gas } \\
\text { emissions per capita, } \\
\text { index of common } \\
\text { farmland bird species, } \\
\text { land fragmentation, } \\
\text { pollutant emissions }\end{array}$ \\
\hline
\end{tabular}




\begin{tabular}{|c|c|c|c|c|c|}
\hline CE monitor & Source & Sustainable sourcing & Cascading use & $\begin{array}{l}\text { Closing the biological } \\
\text { nutrient cycle }\end{array}$ & $\begin{array}{l}\text { Environmental impact } \\
\text { specific to biological } \\
\text { cycles }\end{array}$ \\
\hline CE-enterprise-index & Li and Su, 2012 & & & & $\begin{array}{l}\text { Explicitly but partially } \\
\text { assessed } \\
\text { Assess output per unit } \\
\text { land, water and energy } \\
\text { consumption, emissions } \\
\text { per unit output }\end{array}$ \\
\hline $\begin{array}{l}\text { Circular economy } \\
\text { indicator system of } \\
\text { China }\end{array}$ & Geng et al., 2012 & & & & $\begin{array}{l}\text { Explicitly but partially } \\
\text { assessed } \\
\text { Assess energy } \\
\text { consumption, water } \\
\text { withdrawal, and } \\
\text { emissions per unit } \\
\text { output }\end{array}$ \\
\hline $\begin{array}{l}\text { Regional Circular } \\
\text { Economy Development } \\
\text { Index }\end{array}$ & Guogang and Jing, 2011 & & & & $\begin{array}{l}\text { Explicitly but partially } \\
\text { assessed } \\
\text { Assess water, energy } \\
\text { and chemical fertilizers } \\
\text { consumption }\end{array}$ \\
\hline $\begin{array}{l}\text { Environmental } \\
\text { Protection Indicators in a } \\
\text { context of CE }\end{array}$ & Su et al., 2013 & & & & $\begin{array}{l}\text { Explicitly but partially } \\
\text { assessed } \\
\text { Assess water, energy per } \\
\text { unit output }\end{array}$ \\
\hline $\begin{array}{l}\text { Cradle to cradle } \\
\text { certification program }\end{array}$ & $\begin{array}{l}\text { The Cradle to Cradle } \\
\text { Products Innovation } \\
\text { Institute, } 2014\end{array}$ & & & Explicitly assessed & $\begin{array}{l}\text { Explicitly but partially } \\
\text { assessed } \\
\text { Asses energy and water } \\
\text { consumption }\end{array}$ \\
\hline $\begin{array}{l}\text { Circular economy } \\
\text { performance indicator }\end{array}$ & Huysman et al., 2017 & & Explicitly assessed & & \\
\hline CE indicator system & Zhou et al., 2013 & & & & $\begin{array}{l}\text { Explicitly but partially } \\
\text { assessed, measures } \\
\text { environment damage } \\
\text { cost based on the } \\
\text { economic impact of }\end{array}$ \\
\hline
\end{tabular}




\begin{tabular}{|c|c|c|c|c|c|}
\hline CE monitor & Source & Sustainable sourcing & Cascading use & $\begin{array}{l}\text { Closing the biological } \\
\text { nutrient cycle }\end{array}$ & $\begin{array}{l}\text { Environmental impact } \\
\text { specific to biological } \\
\text { cycles }\end{array}$ \\
\hline & & & & & $\begin{array}{l}\text { environmental pollution } \\
\text { (such as air pollution, } \\
\text { water pollution, light } \\
\text { pollution, noise, solid } \\
\text { waste) }\end{array}$ \\
\hline Eco-efficient value ratio & Scheepens et al., 2016 & & & & \multirow[b]{2}{*}{$\begin{array}{l}\text { Explicitly but partially } \\
\text { assessed, using LCA, } \\
\text { which is a methodology } \\
\text { to study environmental } \\
\text { impact. However, impact } \\
\text { on resource depletion on } \\
\text { ecosystem services and } \\
\text { time-dependent carbon } \\
\text { flows is rarely studied }\end{array}$} \\
\hline $\begin{array}{l}\text { Measuring Regional CE- } \\
\text { Eco-Innovation }\end{array}$ & Smol et al., 2017 & & & & \\
\hline Circulytics & $\begin{array}{l}\text { Ellen MacArthur } \\
\text { Foundation, } 2016\end{array}$ & $\begin{array}{l}\text { Explicitly assessed } \\
\text { (Considers if the biotic } \\
\text { resources are } \\
\text { sustainably sourced) }\end{array}$ & & $\begin{array}{l}\text { Explicitly but partially } \\
\text { assessed } \\
\text { Assess whether the } \\
\text { outflow of material are } \\
\text { suitable for biological } \\
\text { cycle }\end{array}$ & \\
\hline $\begin{array}{l}\text { Global Resource } \\
\text { Indicator }\end{array}$ & Adibi et al., 2017 & $\begin{array}{l}\text { Explicitly but partially } \\
\text { assessed } \\
\text { Assess the renewability } \\
\text { rate while considering } \\
\text { resource scarcity }\end{array}$ & & & \\
\hline $\begin{array}{l}\text { Circularity material } \\
\text { indicator }\end{array}$ & Pauliuk, 2018 & & $\begin{array}{l}\text { Explicitly but partially } \\
\text { assessed, using weighted } \\
\text { factor (based on purity, } \\
\text { quality, and } \\
\text { recoverability of } \\
\text { material) to calculate } \\
\text { circularity index }\end{array}$ & & \\
\hline
\end{tabular}




\begin{tabular}{|l|l|l|l|l|l|}
\hline CE monitor & Source & Sustainable sourcing & Cascading use & $\begin{array}{l}\text { Closing the biological } \\
\text { nutrient cycle }\end{array}$ & $\begin{array}{l}\text { Environmental impact } \\
\text { specific to biological } \\
\text { cycles }\end{array}$ \\
\hline $\begin{array}{l}\text { EU Raw materials } \\
\text { scoreboard }\end{array}$ & European Commission, 2018 & $\begin{array}{l}\text { Explicitly but partially } \\
\text { assessed } \\
\text { Considers growing stock } \\
\text { and forest-felling } \\
\text { (utilization) rate }\end{array}$ & & \\
\hline
\end{tabular}


The study evaluated whether CE monitors assess the sustainable sourcing of biomass; harvested in a way that preserves the ecosystem functioning and long-term provision of resources. Out of $59 \mathrm{CE}$ monitoring frameworks, only 1 considers this aspect. 2 indicators mention the need to consider sustainable harvesting but do not assess it. Whereas 5 indicators implicitly assess it, albeit partially. Out of these 5 indicators, 3 indicators assess the criticality of resources based on economic value ( $\mathrm{Di}$ Maio et al., 2017; Laso et al., 2018; Linder et al., 2017). The assessment based on economic value is considered as an implicit assessment of renewability because, in principle, increased resource scarcity or compromised renewability of resources would reflect on its economic value. However, the use of monetary values has its disadvantages. Market values and prices fluctuate heavily over time. Problems also arise when prices are missing or distorted due to monopolies or government interventions, such as subsidies. Another CE monitor that is considered an implicit assessment is Hybrid LCA, offered by Genovese et al. (2017). Hybrid LCA is a framework to integrate the top-down environmental inputoutput model and bottom-up Life cycle assessment (LCA) model. It has been considered an implicit assessment because the criteria 'sustainable sourcing' will be included if the underlying LCA incorporates the relevant impact categories. The one other indicator that implicitly assesses renewability is 'per capita green area' (Yang et al., 2011). It has been considered an implicit (and partial) assessment because this could ensure that a certain amount of green areas are maintained.

The 4 monitors that explicitly, but partially, assess sustainable sourcing are circularity assessment tool suggested by Circle Economy (Camacho-Otero and Ordoñez, 2017), the EU raw material scoreboard (European Commission, 2018), the global resource indicator (Adibi et al., 2017) and the CE metric proposed by the U.S. Chamber of Commerce Foundation and. The circularity assessment tool of Circle Economy evaluates the renewability and criticality of resources. The EU resource raw material scoreboard considers the growing stock and forest-felling rate. The global resource indicator uses scarcity, recyclability and criticality, wherein scarcity is measured based on renewability rate (Adibi et al., 2017). As discussed in the earlier section (Section 3.1.1), consideration of renewability rate is no guarantee for long-term yield, so these indicators have been considered a partial assessment. The CE metric used by the U.S. Chamber of Commerce Foundation includes a measure of the share of resources from a certified source of that resource, for example, the amount of FSC-certified wood supplied to the furniture and paper industry. Many of the certifications target sustainable management of resources, in particular FSC, which aims for forest management that ensures timber harvesting without affecting the biodiversity, forest productivity and other ecosystem services (FSC, 2015). However, this monitor mentions only FSC certification, which covers forest ecosystems, and it is not clear if the certifications relevant to other ecosystems aim for sustainability in sourcing. The CE monitor has, thus, been marked as a partial assessment.

The only tool that explicitly and completely validates sustainable sourcing of biotic resources is the circularity measurement tool 'Circulytics' developed by Ellen MacArthur Foundation (2020) for companies. It considers the share of virgin resources from renewable and sustainable sources and ensures that the resources are grown in a way that preserves the ecosystems.

To fill the current gap in CE monitors, they should essentially include a renewability score and assess if harvesting is at a level that can preserve the long-term quantity and quality ecosystem functioning. One way of doing that is by adopting methodologies or indicators from other sectors, such as fisheries, forestry. As mentioned earlier, the fisheries sector uses a 'maximum Sustainable Yield' (MSY) as the limit to the fish stock that can be harvested. The sustainable forest management (SFM) indicators, used across Europe, include increment and fellings to assess the provisioning functions of the forests. They additionally use indicators, such as soil conditions, forest damage, land degradation, to monitor 
the overall forest health and vitality (Forest Europe, 2015). Another methodology that can be integrated within CE monitoring is LCA. LCA already has resource depletion as an impact category, based on resource stock, harvest rate and regeneration rate (Guinée and Heijungs, 1995; Heijungs et al., 1997; Klinglmair et al., 2014). The recent developments in the LCA include the assessment of the renewability potential of biotics resources based on the recovery time, restoration time and renewal time (Crenna et al., 2018). These factors are affected by the magnitude of the pressure the ecosystems are subject to and are an indication of ecosystems' health and capacity. To emphasize this issue, Dewulf et al. (2015) suggest that instead of having 'natural resources' as an area of protection, LCA could have 'provisioning capacity of natural resources' as a safeguard subject. These assessments and underlying goals are some of the proposals that could be considered in the CE monitoring frameworks to ensure the sustainable use of biotic resources.

\subsubsection{Optimized cascading use}

The second evaluation of CE tools was validating if it assesses 'cascading use'. This evaluation validated if CE monitors assess resource-quality degradation and if this assessment is performed over multipleuses of the material and over multiple-streams.

Relative to other requirements, a higher number of CE metrics displayed consideration for this category. 14 indicators, out of 59, consider the assessment of cascading. Out of the 3 indicators that implicitly assess it, 2 assume economic value as a proxy for material quality (Linder et al., 2017; Wen and Meng, 2015), while the third one, resource duration indicator or the longevity indicator, measures the contribution to material retention based on the time a resource is in use (Figge et al., 2018; Franklin-Johnson et al., 2016). Increasing the duration of use supports increasing the value-extraction, one of the primary principles of cascading, and has been considered an implicit (and partial) assessment. Amongst the 10 indicators that stress the need to assess material quality instead of mere recycling index, 3 indicators either do not specify the means to do so (Bracquené et al., 2019; Camacho-Otero and Ordoñez, 2017) or highlight that, currently, no data is available to create this indicator (European Environment Agency, 2016).

Among the indicators that explicitly assess cascading, Recycling rates proposed by Haupt et al., 2017 and the Circular economy toolbox by the U.S. Chamber of Commerce Foundation measure closed-loop and open-loop recycling rates. Closed-loop recycling implies using the secondary resources to produce the same product, while open-loop recycling is to produce something that differs from the preceding product. Similarly, Graedel et al. (2011) split recycling rates into end-of-life functional recycling rate and non-functional recycling rate. The functional recycling rate is the portion of resources that are separated and recycled to retain their functions. The non-functional recycling rate describes the share of collected resources recycled to be part of a larger material stream as impurity elements. This prevents the dissipation of this material into the environment but represents the loss of the material's functional properties. Both these indicators acknowledge that often the material loses its quality during recycling, the information regarding which is not captured in the recycling rate. However, none of these indicators considers the extent of quality loss.

Circularity index explicitly considers quality during recycling based on the ratio of the energy required to recover the material from secondary sources (i.e. waste streams) relative to the energy required to produce the material from primary sources (i.e. nature; Cullen, 2017). It is regarded as a partial assessment because the energy required for recovery is technology-specific and might not always represent the material-quality. Another CE tool that explicitly assesses cascading, Circular Economy Index, assumes market value as an indicator of material-quality and measures the ratio of the material market value produced by the recycler by the intrinsic value entering the recycling facility (Di Maio et 
al., 2017). Material recycling index considers recyclate quality as a function of product design and recyclate composition (Van Schaik and Reuter, 2016). However, the product design could be a proxy and not an actual parameter for material quality. These indicators, which explicitly assess cascading, focus on single-step of recycling and appear ineffective for assessment for multiple lifecycles of the material. Circularity material indicator considers a weighted factor based on quality, purity and recoverability to assess the circularity of material (Pauliuk et al., 2017).

Circular Economy Performance Indicator (CPI) is the only metric that successfully evaluates the quality of material flows. CPI indicator is built on the existing recyclability benefit rate (RBR), which is a ratio of environmental benefit from recycling a product over the environmental burden related to production from virgin resources followed by disposal. To integrate the quality loss during recycling into the assessment, the study proposed CPI as the ratio of the actual obtained environmental benefit over the ideal environmental benefit according to quality (Huysman et al., 2017). The latter is the environmental benefit when the waste is re-directed to the state-of-the-art waste treatment option best suited to the waste stream according to its composition or quality. CPI is 1 when the waste is used to the best of its quality (assuming the impact and losses during recycling are minimal). Value of CPI lower than 1 would indicate that the waste stream is not utilised to the best of its technical capability (or the recycling process has a significant material loss or environmental burden). This tool can be aptly used to determine the most appropriate use of waste streams based on their quality, which is one of the key principles of cascading.

The selection of the highest-value application for a material stream, the aspect currently lacking in CE assessment, can be done based on a guiding principle, such as the one adopted by the EU Waste Framework Directive (European Commission, 2008). It provides a waste hierarchy, which set priorities for waste handling techniques. Several other frameworks could aid in this selection process, for example, Lansink's Ladder, Van Gerven's Ladder, Bio-based pyramid (Odegard et al., 2012), food waste hierarchy (Teigiserova et al., 2020). However, these frameworks only set preferences for applications or processes. They do not state the application best suited for the resource based on the inherent resource properties and the application that necessitates these properties the most. Methodologies that evaluate the intrinsic material properties, such as statistical entropy analysis (SEA) or exergy analysis, could support filling this gap. SEA has been put forward as a method to quantify resource quality (Laner et al., 2017) based on the concentration of a substance in a flow (Rechberger and Graedel, 2002). The higher the concentration of a substance in a flow, the higher is its availability and, hence, the higher is the potential utility. SEA could also quantify quality based on other physical properties that determine the material utility. For example - for wood, the size of the wooden element defines its utility. Sawn-wood has a higher utility than wood chips. SEA applied to the entire lifecycle of material, as done in Laner et al. (2017) and Rechberger and Graedel (2002), reflects changes in the resource quality over time. The resource-use pathway that maximally preserves quality and materialvalue over time can be considered the most desirable material trajectory. SEA includes all the three aspects - quality degradation, multiple life cycles \& multiple streams - relevant for cascading and, thus, could be a powerful tool for assessing it. Exergy analysis uses the thermodynamic-based exergy concept, which is the maximum potential work that can be obtained from the resource when bringing it into equilibrium through reversible processes with the natural environment (Dewulf et al., 2008). Resource-quality degradation is represented with the loss of potential energy, and hence the exergy approach too could be viable to study cascading. The use of exergy analysis to study cascading use has already been demonstrated by Risse et al. (2017). While SEA and exergy analysis can identify the highest-value material trajectory, complementary methods, such as LCA, support improve the resource-efficiency and reduce the environmental burden of that material trajectory (Dewulf et al., 2008; Kaufman et al., 2008; Rechberger and Brunner, 2002). Methods such as these should be 
integrated into the CE assessment frameworks to ensure the cascading use of biotic resources is optimized.

\subsubsection{Closing the biological nutrient cycle}

The third aspect that was evaluated refers to the closing of the biological nutrient cycle and validates if the CE monitors assess:

1. The biodegradability of the bio-based material - i.e. it safely returns to the biosphere and does not accumulate in the environment

2. The presence and toxicity of hazardous substances in the emissions to the environment as a result of biodegradation

3. The biotic resources returning to the biosphere as nutrients sustain the regeneration of the ecological systems

It is observed that out of 59 CE indicators that were studied, only 1 indicator completely studied the end-of-life of biotic resources. Additional 8 indicators assess only a part of the criteria of biological nutrient loop closing.

The indicators that partially assess the end-of-life of bio-based material validate whether it is biodegradable or compostable. The circularity measurement tool 'Circulytics', developed by Ellen MacArthur Foundation (2020), evaluates the share of the total output flows, products and waste that are suitable for the biological cycle, i.e. that degrade and not cause harm to human health or the environment during or after their use. EU Resource efficiency scoreboard (European Commission, 2015) evaluates whether the nutrients from end-of-life return as feedstock to the ecosystems. The indictors for that are area under organic farming, soil erosion and gross nutrient balance in agricultural land. The scoreboard focuses on the agricultural systems, and the evaluation of other biomass production systems, such as forestry and marine, is overlooked. The only indicator that evaluates biological nutrient loop closing is the Cradle to Cradle Certification Program. The assessment for this certification validates if the companies pursuing certification define components of their products as biological or technical nutrients, and design pathways for nutrient recovery and re-utilization (The Cradle to Cradle Products Innovation Institute, 2014).

CE monitors should include, equivalent to the recyclability score for technical cycles, a biodegradability score for end-of-product-life bio-based materials. The monitors should also assess any potential risk of the presence of non-biodegradable elements in the waste streams re-introduced in the biosphere or atmosphere. Additionally and more importantly, for the streams that safely return to the biosphere, the CE assessment should assess the extent to which nutrients contribute to biomass regeneration. The monitor could be by evaluating regional-scale management of organic waste, i.e. plant nutrients, sewage sludge and livestock manure (Mayer et al., 2019), and assessing the ecosystem services, such as soil fertility, water quality and availability, biodiversity. Both places - where resources are extracted and where nutrients are deposited - should be monitored to avoid damaging the ecosystems at either location.

\subsubsection{Assess the environmental impact associated with biological cycle}

The fourth element evaluated in this study is whether the environmental impacts, associated with biotic resource extraction and the temporal aspect of carbon fluxes, are being assessed in the CE monitoring frameworks. The study evaluated whether the environmental impact assessments considered impacts of biotic resource extraction, resulting from land-use interventions and resource depletion, on ecosystem services. And concerning the environmental impact due to biogenic carbon emissions, the study evaluated if the CE monitors validate carbon-neutrality of biological cycles, by 
accounting for the rate of carbon sequestration, the amount of time over which carbon is stored and the rate of release of biogenic carbon.

Only 11 out of 59 CE monitors assess environmental impact, but even they are not are complete. The framework defined by the European Environmental Agency mentions that the use of bio-based material can damage biodiversity and ecosystem services, and contribute to climate change, however, does not assess it (European Environment Agency, 2016). Other CE assessment frameworks do evaluate the environmental impact of biotic resource use but do so insufficiently. Many of them measure ecological efficiency in terms of land area, water consumption, energy consumption and emissions (especially $\mathrm{SO}_{2}$ ) per unit output (Geng et al., 2012; Li and Su, 2012; Su et al., 2013; The Cradle to Cradle Products Innovation Institute, 2014). The Regional Circular Economy Development Index developed by Guogang and Jing (2011), in addition, also measures the amount of chemical fertilizers applied per unit planted area. These indicators are insufficient to gauge the total ecosystem impact of biotic resource depletion and land-use. Additionally, carbon accounting is not present in these listings. The EU Resource efficiency scoreboard has a comparatively wider range of indicators, including an index of common farmland bird species, the extent of land fragmentation and soil erosion. This scoreboard does include greenhouse gas (GHG) emissions, but the emissions from the use of biomass and stock changes in forests are not included. The CE indicator system developed by Zhou et al. (2013) assesses the external environment damage cost caused due to the production process, i.e. the ecological damage originating from the over-consumption of natural resources. This metric assesses the impact on ecosystem services, but it is also incomplete.

The remaining indicators base their assessment on LCA methodology (Genovese et al., 2017; Scheepens et al., 2016; Smol et al., 2017). For instance, Scheepens et al. (2016) apply the LCA-based Eco-costs Value Ratio (EVR) model to analyze the potentially negative environmental effects of business initiatives. LCA is a widely used methodology to assess environmental impact. However, the environmental impacts associated with land use and biotic resources depletion is not always fully integrated or widely applied in many LCA studies (Heijungs et al., 1997; Koellner et al., 2013; Wagendorp et al., 2006). For the aspect of carbon balance, contribution to climate change (in LCA terminology - global warming potential GWP) is often a central part of LCA, but consideration of the temporal aspect of emissions is often lacking (Levasseur et al., 2010). This suggests a clear need to explicitly include these aspects in CE monitoring for a complete assessment of the impact of bio-based materials or biological cycles.

There are increasing attempts to evaluate impacts on biodiversity and ecosystem quality. Existing indicators, such as ecological footprint, agricultural land footprint, forest footprint, could be adopted in the CE monitors to close the current gap. Even for the LCA approach, concrete proposals have been put forward to incorporate the impact of biotic resource extraction, resulting from land-use \& landuse change and resource depletion, on biodiversity and ecosystem health. Impact due to land-use interventions is based on the type of landscape that is disturbed and the duration of the disturbance (Heijungs et al., 1997), which considers the current occupation of land and change in land-use, which affects the natural regeneration time and biodiversity (Koellner et al., 2013; Lindeijer, 2000). Wagendorp et al., 2006 provided an LCA based assessment for land use impact based on ecosystem thermodynamics. Human impact, such as reduced biomass, is indicated in this study by a decrease of exergy, which is converse to what the ecosystem strives to achieve. Schmidt et al. (2015) provided a framework for evaluating the indirect land-use change. Koellner et al. (2013) proposed structured guidelines to assess the damages caused by land-use interventions on biodiversity and ecosystem services. This framework includes two impact pathways - biodiversity damage potential, based on the functional diversity of species in ecosystems, and ecosystem services damage potential, based on the 
impact on the potential of the ecosystem to produce biomass, the impact on climate and the impacts on water and soil quantity and quality.

Crenna et al. (2018) evaluated the consequence of biotic resources depletion on ecosystem quality. Crenna et al. (2019) showcases, using the preliminary LCA based impact assessment framework, the role of EU food consumption in the current biodiversity decline. They studied the impact of the food system on different impact categories (climate change, eutrophication etc.) and then measured the rate of species lost in a particular area of land or volume of water during a particular time due to these impacts. A different perspective has been proposed by Dewulf et al. (2015) to acknowledge this issue. They recommend that instead of having 'natural resources' as an area of protection, LCA could have the 'ecosystem functions or services' as a safeguard subject. For instance, instead of considering wood from the forest as an asset to be protected, the functions trees provide to the ecosystem (e.g. climate regulation, water purification) should be protected. These are proposals for bridging the gaps in LCA, but could also be relevant for CE monitoring.

Concerning carbon accounting in LCA, carbon sequestration during biomass growth is commonly accounted as negative emissions. But the temporal profile of carbon sequestration, storage and emissions are not often considered (De Rosa et al., 2017). The attention towards this time-dependent accounting of biogenic carbon flows has recently increased (Levasseur et al., 2010). Several methodologies aim to integrate it in mainstream LCA (De Rosa et al., 2017), building on a timedependent life-cycle inventory data, which details emissions and sequestrations through time (i.e., the amount of carbon released or absorbed at every given time-step). The dynamics of carbon flux significantly influence the LCA results, and therefore it is crucial to integrate the time-frames to accurately assess the global warming impact of the use of bio-based materials and biological cycles.

\section{Conclusion}

The use of biotic resources is not necessarily circular and sustainable. Thus, a critical evaluation of the biological cycles is essential in the context of $\mathrm{CE}$, which is currently lacking. For more circular biological systems, biotic resources should be sourced at a rate that ensures their long-term yields, should follow an optimized cascading use pathway and should decompose at the end of their product life and return to the biosphere to support the regeneration of the ecosystem. The processed bio-based materials that do not decompose should be treated as part of a technical cycle and should be looped back in the technosphere to maintain their material-value for as long as possible. Additionally, the biological cycles have an environmental impact, specifically from resource extraction and biogenic carbon emissions. Biotic resource extraction has a damaging effect on biodiversity, ecosystem health and functioning, due to resource depletion and direct and indirect land-use change. These impacts should be closely monitored within circularity frameworks. The use of bio-based materials is being encouraged because of their potential environmental benefit over their fossil counterpart, which will likely increase the demand for biotic resources. The circularity of biological cycles should be analyzed to avoid overexploitation of natural resources and further degradation of ecosystems.

Therefore, a thorough CE monitoring of the biological cycles should assess (1) sustainable sourcing (2) cascading use of materials (3) the extent to which nutrients effectively re-enter the biological cycles and (4) the environmental impact of sourcing biotic resources and carbon fluxes. These assessments do not necessarily have to be newly developed. Existing indicators and assessment frameworks from different sectors could assist in filling the gap. This study highlights that bridging the gaps in current CE assessment and making them apt also for biological cycles is crucial and would be a step forward in ensuring sustainable and circular use of natural resources. 
277 The authors declare that they have no known competing financial interests or personal relationships that could have appeared to influence the work reported in this paper.

\section{Acknowledgment}

This research is funded by the Flemish Institute for Technological Research (VITO) and is a cooperation between VITO and KU Leuven. The authors would like to thank the reviewer Walter Eevers for the discussion of ideas and challenging of the conclusions, which contributed to improving the quality of this study.

\section{CRediT author statement}

Kranti Navare: Conceptualization, Methodology, Writing - Original Draft, Writing - Review \& Editing. Bart Muys: Writing - Review \& Editing, Supervision. Karl C. Vrancken: Writing - Review \& Editing, Supervision. Karel Van Acker: Writing - Review \& Editing, Supervision, Project administration.

\section{References}

Adibi, N., Lafhaj, Z., Yehya, M., Payet, J., 2017. Global Resource Indicator for life cycle impact assessment: Applied in wind turbine case study. J. Clean. Prod. 165, 1517-1528. https://doi.org/10.1016/j.jclepro.2017.07.226 Airoldi, L., Beck, M.W., 2007. Loss, status and trends for coastal marine habitats of Europe, Oceanography and Marine Biology. https://doi.org/10.1201/9781420050943.ch7

Alaerts, L., Augustinus, M., Van Acker, K., 2018. Impact of Bio-Based Plastics on Current Recycling of Plastics. Sustainability 10, 1487. https://doi.org/10.3390/su10051487

Andersen, M.S., 2007. An introductory note on the environmental economics of the circular economy. Sustain. Sci. 2, 133-140. https://doi.org/10.1007/s11625-006-0013-6

Bais-Moleman, A.L., Sikkema, R., Vis, M., Reumerman, P., Theurl, M.C., Erb, K.H., 2017. Assessing wood use efficiency and greenhouse gas emissions of wood product cascading in the European Union. J. Clean. Prod. 172, 3942-3954. https://doi.org/10.1016/j.jclepro.2017.04.153

Battye, W., Aneja, V.P., Schlesinger, W.H., 2017. Is nitrogen the next carbon? Earth's Futur. 5, 894-904. https://doi.org/10.1002/2017EF000592

Beylot, A., Ardente, F., Sala, S., Zampori, L., 2020. Accounting for the dissipation of abiotic resources in LCA: Status, key challenges and potential way forward. Resour. Conserv. Recycl. 157, 104748. https://doi.org/10.1016/j.resconrec.2020.104748

Bocken, N.M.P., de Pauw, I., Bakker, C., van der Grinten, B., 2016. Product design and business model strategies for a circular economy. J. Ind. Prod. Eng. 33, 308-320. https://doi.org/10.1080/21681015.2016.1172124

Bracquené, E., Dewulf, W., Duflou, J.R., 2019. Measuring the performance of more circular complex product supply chains. Resour. Conserv. Recycl. 154, 104608. https://doi.org/10.1016/j.resconrec.2019.104608

Braungart, M., McDonough, W., Bollinger, A., 2007. Cradle-to-cradle design: creating healthy emissions - a strategy for eco-effective product and system design. J. Clean. Prod. 15, 1337-1348. https://doi.org/10.1016/J.JCLEPRO.2006.08.003

Brunet-Navarro, P., Jochheim, H., Kroiher, F., Muys, B., 2018. Effect of cascade use on the carbon balance of the German and European wood sectors. J. Clean. Prod. 170, 137-146. https://doi.org/10.1016/J.JCLEPRO.2017.09.135

Camacho-Otero, J., Ordoñez, I., 2017. Circularity assessment in companies: conceptual elements for developing assessment tools.

Campbell-Johnston, K., Vermeulen, W.J.V., Reike, D., Brullot, S., 2020. The Circular Economy and Cascading: Towards a Framework. Resour. Conserv. Recycl. X. https://doi.org/10.1016/j.rcrx.2020.100038

Ceccherini, G., Duveiller, G., Grassi, G., Lemoine, G., Avitabile, V., Pilli, R., Cescatti, A., 2020. Abrupt increase in harvested forest area over Europe after 2015. Nature 583, 72-77. https://doi.org/10.1038/s41586-0202438-y 
Chapin, F.S., Zavaleta, E.S., Eviner, V.T., Naylor, R.L., Vitousek, P.M., Reynolds, H.L., Hooper, D.U., Lavorel, S., Sala, O.E., Hobbie, S.E., Mack, M.C., Díaz, S., 2000. Consequences of changing biodiversity. Nature. https://doi.org/10.1038/35012241

Chowdhury, R.B., Moore, G.A., Weatherley, A.J., Arora, M., 2014. A review of recent substance flow analyses of phosphorus to identify priority management areas at different geographical scales. Resour. Conserv. Recycl. https://doi.org/10.1016/j.resconrec.2013.10.014

Cline, S.P., Smith, P.M., 2017. Opportunities for lignin valorization: an exploratory process. Energy. Sustain. Soc. 7, 1-12. https://doi.org/10.1186/s13705-017-0129-9

Coppens, J., Meers, E., Boon, N., Buysse, J., Vlaeminck, S.E., 2016. Follow the N and P road: High-resolution nutrient flow analysis of the Flanders region as precursor for sustainable resource management. Resour. Conserv. Recycl. 115, 9-21. https://doi.org/10.1016/j.resconrec.2016.08.006

Corona, B., Shen, L., Reike, D., Rosales Carreón, J., Worrell, E., 2019. Towards sustainable development through the circular economy-A review and critical assessment on current circularity metrics. Resour. Conserv. Recycl. https://doi.org/10.1016/j.resconrec.2019.104498

Crenna, E., Sinkko, T., Sala, S., 2019. Biodiversity impacts due to food consumption in Europe. J. Clean. Prod. 227, 378-391. https://doi.org/10.1016/j.jclepro.2019.04.054

Crenna, E., Sozzo, S., Sala, S., 2018. Natural biotic resources in LCA: Towards an impact assessment model for sustainable supply chain management. J. Clean. Prod. 172, 3669-3684. https://doi.org/10.1016/j.jclepro.2017.07.208

Cullen, J.M., 2017. Circular Economy: Theoretical Benchmark or Perpetual Motion Machine? J. Ind. Ecol. 21, 483486. https://doi.org/10.1111/jiec.12599

Dalin, C., Rodríguez-Iturbe, I., 2016. Environmental impacts of food trade via resource use and greenhouse gas emissions. Environ. Res. Lett. 11. https://doi.org/10.1088/1748-9326/11/3/035012

De Oliveira Garcia, W., Amann, T., Hartmann, J., 2018. Increasing biomass demand enlarges negative forest nutrient budget areas in wood export regions. Sci. Rep. 8, 5280. https://doi.org/10.1038/s41598-01822728-5

De Rosa, M., Schmidt, J., Brandão, M., Pizzol, M., 2017. A flexible parametric model for a balanced account of forest carbon fluxes in LCA. Int. J. Life Cycle Assess. 22, 172-184. https://doi.org/10.1007/s11367-0161148-z

Dewulf, J., Benini, L., Mancini, L., Sala, S., Blengini, G.A., Ardente, F., Recchioni, M., Maes, J., Pant, R., Pennington, D., 2015. Rethinking the area of protection "natural resources" in life cycle assessment. Environ. Sci. Technol. 49, 5310-5317. https://doi.org/10.1021/acs.est.5b00734

Dewulf, J., Van Langenhove, H., Muys, B., Bruers, S., Bakshi, B.R., Grubb, G.F., Paulus, D.M., Sciubba, E., 2008. Exergy: Its potential and limitations in environmental science and technology. Environ. Sci. Technol. https://doi.org/10.1021/es071719a

Di Maio, F., Rem, P.C., 2015. A Robust Indicator for Promoting Circular Economy through Recycling. J. Environ. Prot. (Irvine,. Calif). 06, 1095-1104. https://doi.org/10.4236/jep.2015.610096

Di Maio, F., Rem, P.C., Baldé, K., Polder, M., 2017. Measuring resource efficiency and circular economy: A market value approach. Resour. Conserv. Recycl. 122, 163-171. https://doi.org/10.1016/j.resconrec.2017.02.009

Elia, V., Gnoni, M.G., Tornese, F., 2017. Measuring circular economy strategies through index methods: A critical analysis. J. Clean. Prod. 142, 2741-2751. https://doi.org/10.1016/j.jclepro.2016.10.196

Ellen MacArthur Foundation, 2020. Circulytics - Indicator list.

Ellen MacArthur Foundation, 2017. Urban Biocycles, Ellen MacArthur Foundation.

Ellen MacArthur Foundation, 2015. Circularity Indicators - An Approach to Measuring Circularity, Ellen MacArthur Foundation.

Ellen MacArthur Foundation, 2010. Towards a circular economy: Business rationale for an accelerated transition. https://doi.org/2012-04-03

Essel, R., Breitmayer, E., Carus, M., Fehrenbach, H., von Geibler, D.J., Bienge, K., Baur, P.F., 2008. Discussion paper - Defining cascading use of biomass. Intern. Med. J. 38, 259-264. https://doi.org/10.1111/j.14455994.2007.01480.x

European Commission, 2018. EU Raw Materials Scoreboard, European Commission. https://doi.org/10.2873/13314

European Commission, 2015. EU Resource Efficiency Scoreboard 2015. https://doi.org/http://dx.doi.org/10.1016/j.jalz.2011.05.2410

European Commission, 2012. Innovating for sustainable growth: A bioeconomy for Europe, Industrial Biotechnology. https://doi.org/10.1089/ind.2012.1508

European Commission, 2008. DIRECTIVE 2008/98/EC on waste and repealing certain Directives, Official Journal 
of the European Union. https://doi.org/10.1016/j.jpdc.2017.02.002

European Environment Agency, 2016. Circular economy in Europe - Developing the knowledge base. https://doi.org/10.2800/51444

European Environmental Agency, 2018. The circular economy and the bioeconomy. https://doi.org/10.2800/02937

Evans, J.L., Bocken, N.M.P., 2014. A tool for manufacturers to find opportunity in the circular economy: www.circulareconomytoolkit.org. KES Trans. Sustain. Des. Manuf. I 303-320.

Fargione, J., Hill, J., Tilman, D., Polasky, S., Hawthorne, P., 2008. Land clearing and the biofuel carbon debt. Science (80-. ). 319, 1235-1238. https://doi.org/10.1126/science.1152747

Figge, F., Thorpe, A.S., Givry, P., Canning, L., Franklin-Johnson, E., 2018. Longevity and Circularity as Indicators of Eco-Efficient Resource Use in the Circular Economy. Ecol. Econ. 150, 297-306. https://doi.org/10.1016/J.ECOLECON.2018.04.030

Foley, J.A., DeFries, R., Asner, G.P., Barford, C., Bonan, G., Carpenter, S.R., Chapin, F.S., Coe, M.T., Daily, G.C., Gibbs, H.K., Helkowski, J.H., Holloway, T., Howard, E.A., Kucharik, C.J., Monfreda, C., Patz, J.A., Prentice, I.C., Ramankutty, N., Snyder, P.K., 2005. Global consequences of land use, Science. https://doi.org/10.1126/science.1111772

Forest Europe, 2015. Madrid Ministerial Declaration 25 years together promoting Sustainable Forest Management in Europe.

Fraanje, P.J., 1999. Use of wood in new Dutch one family dwellings since 1969. Holz als Roh - und Werkst. 57, 407-417. https://doi.org/10.1007/s001070050065

Fraanje, P.J., 1997. Cascading of pine wood. Resour. Conserv. Recycl. 19, 21-28. https://doi.org/10.1016/S09213449(96)01159-7

Franklin-Johnson, E., Figge, F., Canning, L., 2016. Resource duration as a managerial indicator for Circular Economy performance. J. Clean. Prod. 133, 589-598. https://doi.org/10.1016/J.JCLEPRO.2016.05.023

FSC, 2015. FSC Principles and Criteria for Forest Stewardship - Draft Version 521.

Geng, Y., Fu, J., Sarkis, J., Xue, B., 2012. Towards a national circular economy indicator system in China: An evaluation and critical analysis. J. Clean. Prod. 23, 216-224. https://doi.org/10.1016/j.jclepro.2011.07.005

Genovese, A., Acquaye, A.A., Figueroa, A., Koh, S.C.C.L., 2017. Sustainable supply chain management and the transition towards a circular economy: Evidence and some applications. Omega (United Kingdom) 66, 344357. https://doi.org/10.1016/j.omega.2015.05.015

Graedel, T.E., Allwood, J., Birat, J.P., Buchert, M., Hagelüken, C., Reck, B.K., Sibley, S.F., Sonnemann, G., 2011. What do we know about metal recycling rates? J. Ind. Ecol. 15, 355-366. https://doi.org/10.1111/j.15309290.2011.00342.x

Guinée, J.B., Heijungs, R., 1995. A proposal for the definition of resource equivalency factors for use in product life-cycle assessment. Environ. Toxicol. Chem. 14, 917-925. https://doi.org/10.1002/etc.5620140525

Guogang, J., Jing, C., 2011. Research on Evaluation of Circular Economy Development. Proc. 8Th Int. Conf. Innov. Manag. 153+.

Haas, W., Krausmann, F., Wiedenhofer, D., Lauk, C., Mayer, A., 2020. Spaceship earth's odyssey to a circular economy - a century long perspective. Resour. Conserv. Recycl. 163, 105076. https://doi.org/10.1016/j.resconrec.2020.105076

Haberl, H., Geissler, S., 2000. Cascade utilization of biomass: Strategies for a more efficient use of a scarce resource. Ecol. Eng. 16, 111-121. https://doi.org/10.1016/s0925-8574(00)00059-8

Haupt, M., Vadenbo, C., Hellweg, S., 2017. Do We Have the Right Performance Indicators for the Circular Economy?: Insight into the Swiss Waste Management System. J. Ind. Ecol. 21, 615-627. https://doi.org/10.1111/jiec.12506

Heijungs, R., Guinée, J.B., Huppes, G., 1997. Impact categories for natural resources and land use- Survey and analysis of existing and proposed methods in the context of environmental life cycle assessment.

Hennig, C., Brosowski, A., Majer, S., 2016. Sustainable feedstock potential - A limitation for the bio-based economy? J. Clean. Prod. 123, 200-202. https://doi.org/10.1016/j.jclepro.2015.06.130

Hetemäki, L., Aho, E., Narbona Ruiz, C., Persson, G., Potočnik, J., 2017. Leading the way to a European circular bioeconomy strategy. From Science to Policy 5., European Forest Institute.

Hilborn, R., Walters, C.J., Ludwig, D., 1995. Sustainable Exploitation of Renewable Resources, Annual Review of Ecology and Systematics. https://doi.org/10.1146/annurev.ecolsys.26.1.45

Höglmeier, K., Steubing, B., Weber-Blaschke, G., Richter, K., 2015. LCA-based optimization of wood utilization under special consideration of a cascading use of wood. J. Environ. Manage. 152, 158-170. https://doi.org/10.1016/j.jenvman.2015.01.018

HögImeier, K., Weber-Blaschke, G., Richter, K., 2013. Potentials for cascading of recovered wood from building 
deconstruction-A case study for south-east Germany. Resour. Conserv. Recycl. 78, 81-91. https://doi.org/10.1016/J.RESCONREC.2013.07.004

Huysman, S., De Schaepmeester, J., Ragaert, K., Dewulf, J., De Meester, S., 2017. Performance indicators for a circular economy: A case study on post-industrial plastic waste. Resour. Conserv. Recycl. 120, 46-54. https://doi.org/10.1016/J.RESCONREC.2017.01.013

Jarre, M., Petit-Boix, A., Priefer, C., Meyer, R., Leipold, S., 2020. Transforming the bio-based sector towards a circular economy - What can we learn from wood cascading? For. Policy Econ. https://doi.org/10.1016/j.forpol.2019.01.017

Jiang, T., Duan, Q., Zhu, J., Liu, H., Yu, L., 2020. Starch-based biodegradable materials: Challenges and opportunities. Adv. Ind. Eng. Polym. Res. 3, 8-18. https://doi.org/10.1016/j.aiepr.2019.11.003

Kaiser, M.J., Collie, J.S., Hall, S.J., Jennings, S., Poiner, I.R., 2002. Modification of marine habitats by trawling activities: Prognosis and solutions. Fish Fish. 3, 114-136. https://doi.org/10.1046/j.14672979.2002.00079.x

Kalmykova, Y., Harder, R., Borgestedt, H., Svanäng, I., 2012. Pathways and Management of Phosphorus in Urban Areas. J. Ind. Ecol. 16, 928-939. https://doi.org/10.1111/j.1530-9290.2012.00541.x

Kalmykova, Y., Sadagopan, M., Rosado, L., 2018. Circular economy - From review of theories and practices to development of implementation tools. Resour. Conserv. Recycl. 135, 190-201. https://doi.org/10.1016/J.RESCONREC.2017.10.034

Kalverkamp, M., Pehlken, A., Wuest, T., 2017. Cascade use and the management of product lifecycles. Sustain. 9, 1540. https://doi.org/10.3390/su9091540

Kaufman, S., Krishnan, N., Kwon, E., Castaldi, M., Themelis, N., Rechberger, H., 2008. Examination of the fate of carbon in waste management systems through statistical entropy and life cycle analysis. Environ. Sci. Technol. 42, 8558-8563. https://doi.org/10.1021/es8007497

Keegan, D., Kretschmer, B., Elbersen, B., Panoutsou, C., 2013. Cascading use: a systematic approach to biomass beyond the energy sector. Biofuels, Bioprod. Biorefining 7, 193-206. https://doi.org/10.1002/bbb.1351

Kirchherr, J., Reike, D., Hekkert, M., 2017. Conceptualizing the circular economy: An analysis of 114 definitions. Resour. Conserv. Recycl. 127, 221-232. https://doi.org/10.1016/J.RESCONREC.2017.09.005

KlingImair, M., Sala, S., Brandão, M., 2014. Assessing resource depletion in LCA: A review of methods and methodological issues. Int. J. Life Cycle Assess. 19, 580-592. https://doi.org/10.1007/s11367-013-0650-9

Koellner, T., Baan, L., Beck, T., Brandão, M., Civit, B., Margni, M., Canals, L.M., Saad, R., Souza, D.M., MüllerWenk, R., 2013. UNEP-SETAC guideline on global land use impact assessment on biodiversity and ecosystem services in LCA. Int. J. Life Cycle Assess. 18, 1188-1202. https://doi.org/10.1007/s11367-0130579-z

Koffler, C., Florin, J., 2013. Tackling the downcycling issue - A revised approach to value-corrected substitution in life cycle assessment of aluminum (VCS 2.0). Sustain. 5, 4546-4560. https://doi.org/10.3390/su5114546

Koh, L.P., Ghazoul, J., 2008. Biofuels, biodiversity, and people: Understanding the conflicts and finding opportunities. Biol. Conserv. https://doi.org/10.1016/j.biocon.2008.08.005

Korhonen, J., Nuur, C., Feldmann, A., Birkie, S.E., 2018. Circular economy as an essentially contested concept. J. Clean. Prod. 175, 544-552. https://doi.org/10.1016/j.jclepro.2017.12.111

Laner, D., Zoboli, O., Rechberger, H., 2017. Statistical entropy analysis to evaluate resource efficiency: Phosphorus use in Austria. Ecol. Indic. 83, 232-242. https://doi.org/10.1016/j.ecolind.2017.07.060

Laso, J., García-Herrero, I., Margallo, M., Vázquez-Rowe, I., Fullana, P., Bala, A., Gazulla, C., Irabien, Á., Aldaco, R., 2018. Finding an economic and environmental balance in value chains based on circular economy thinking: An eco-efficiency methodology applied to the fish canning industry. Resour. Conserv. Recycl. 133, 428-437. https://doi.org/10.1016/j.resconrec.2018.02.004

Lassaletta, L., Billen, G., Grizzetti, B., Garnier, J., Leach, A.M., Galloway, J.N., 2014. Food and feed trade as a driver in the global nitrogen cycle: 50-year trends. Biogeochemistry 118, 225-241. https://doi.org/10.1007/s10533-013-9923-4

Lathuillière, M.J., Johnson, M.S., Galford, G.L., Couto, E.G., 2014. Environmental footprints show China and Europe's evolving resource appropriation for soybean production in Mato Grosso, Brazil. Environ. Res. Lett. 9. https://doi.org/10.1088/1748-9326/9/7/074001

Leipold, S., Petit-Boix, A., 2018. The circular economy and the bio-based sector - Perspectives of European and German stakeholders. J. Clean. Prod. 201, 1125-1137. https://doi.org/10.1016/j.jclepro.2018.08.019

Levasseur, A., Lesage, P., Margni, M., Deschěnes, L., Samson, R., 2010. Considering time in LCA: Dynamic LCA and its application to global warming impact assessments. Environ. Sci. Technol. 44, 3169-3174. https://doi.org/10.1021/es9030003

Li, R.H., Su, C.H., 2012. Evaluation of the circular economy development level of Chinese chemical enterprises. 
Procedia Environ. Sci. 13, 1595-1601. https://doi.org/10.1016/J.PROENV.2012.01.151

Liao, Y., Koelewijn, S.F., van den Bossche, G., van Aelst, J., van den Bosch, S., Renders, T., Navare, K., Nicolaï, T., van Aelst, K., Maesen, M., Matsushima, H., Thevelein, J.M., van Acker, K., Lagrain, B., Verboekend, D., Sels, B.F., 2020. A sustainable wood biorefinery for low-carbon footprint chemicals production. Science (80-. ). 367, 1385-1390. https://doi.org/10.1126/science.aau1567

Lindeijer, E., 2000. Review of land use impact methodologies. J. Clean. Prod. 8, 273-281. https://doi.org/10.1016/S0959-6526(00)00024-X

Linder, M., Sarasini, S., van Loon, P., 2017. A Metric for Quantifying Product-Level Circularity. J. Ind. Ecol. 21, 545-558. https://doi.org/10.1111/jiec.12552

Marini, M., Angouria-Tsorochidou, E., Caro, D., Thomsen, M., 2021. Daily intake of heavy metals and minerals in food - A case study of four Danish dietary profiles. J. Clean. Prod. 280, 124279. https://doi.org/10.1016/j.jclepro.2020.124279

Maunder, M.N., 2008. Maximum Sustainable Yield, in: Encyclopedia of Ecology, Five-Volume Set. Elsevier Inc., pp. 2292-2296. https://doi.org/10.1016/B978-008045405-4.00522-X

Mayer, A., Haas, W., Wiedenhofer, D., Krausmann, F., Nuss, P., Blengini, G.A., 2019. Measuring Progress towards a Circular Economy: A Monitoring Framework for Economy-wide Material Loop Closing in the EU28. J. Ind. Ecol. 23, 62-76. https://doi.org/10.1111/jiec.12809

Merrild, H., Christensen, T.H., 2009. Recycling of wood for particle board production: accounting of greenhouse gases and global warming contributions. ISSN 0734-242X Waste Manag. Res. 27, 781-788. https://doi.org/10.1177/0734242X09349418

Moraga, G., Huysveld, S., Mathieux, F., Blengini, G.A., Alaerts, L., Van Acker, K., de Meester, S., Dewulf, J., 2019. Circular economy indicators: What do they measure? Resour. Conserv. Recycl. 146, 452-461. https://doi.org/10.1016/j.resconrec.2019.03.045

Muys, B., Hetemäki, L., Palahi, M., 2013. Sustainable wood mobilization for EU renewable energy targets. Biofuels, Bioprod. Biorefining. https://doi.org/10.1002/bbb.1421

Muys, B., Masiero, M., Achten, W.M.J., 2014. Sustainability issues of using forests as a bioenergy resource, in: Forest Bioenergy for Europe. pp. 90-97.

Odegard, I., Croezen, H., Bergsma, G., 2012. Cascading of Biomass: 13 Solutions for a Sustainable Bio-based Economy-Making Better Choices for Use of Biomass Residues, By-products and Wastes, CE Delft.

Papangelou, A., Achten, W.M.J., Mathijs, E., 2020. Phosphorus and energy flows through the food system of Brussels Capital Region. Resour. Conserv. Recycl. 156, 104687. https://doi.org/10.1016/j.resconrec.2020.104687

Parchomenko, A., Nelen, D., Gillabel, J., Rechberger, H., 2019. Measuring the circular economy - A Multiple Correspondence Analysis of 63 metrics. J. Clean. Prod. 210, 200-216. https://doi.org/10.1016/j.jclepro.2018.10.357

Pauliuk, S., 2018. Critical appraisal of the circular economy standard BS 8001:2017 and a dashboard of quantitative system indicators for its implementation in organizations. Resour. Conserv. Recycl. 129, 8192. https://doi.org/10.1016/J.RESCONREC.2017.10.019

Pauliuk, S., Kondo, Y., Nakamura, S., Nakajima, K., 2017. Regional distribution and losses of end-of-life steel throughout multiple product life cycles-Insights from the global multiregional MaTrace model. Resour. Conserv. Recycl. 116, 84-93. https://doi.org/10.1016/j.resconrec.2016.09.029

Pizzol, M., Thomsen, M., Andersen, M.S., 2010. Long-term human exposure to lead from different media and intake pathways. Sci. Total Environ. 408, 5478-5488. https://doi.org/10.1016/j.scitotenv.2010.07.077

Rechberger, H., Brunner, P.H., 2002. A new, entropy based method to support waste and resource management decisions. Environ. Sci. Technol. 36, 809-16. https://doi.org/Doi 10.1021/Es010030h

Rechberger, H., Graedel, T.E., 2002. The contemporary European copper cycle: statistical entropy analysis. Ecol. Econ. 42, 59-72. https://doi.org/10.1016/S0921-8009(02)00102-7

Reijnders, L., 2008. Are emissions or wastes consisting of biological nutrients good or healthy? J. Clean. Prod. https://doi.org/10.1016/j.jclepro.2008.02.003

Risse, M., Weber-Blaschke, G., Richter, K., 2017. Resource efficiency of multifunctional wood cascade chains using LCA and exergy analysis, exemplified by a case study for Germany. Resour. Conserv. Recycl. 126, 141-152. https://doi.org/10.1016/j.resconrec.2017.07.045

Rossi, E., Bertassini, A.C., Ferreira, C. dos S., Neves do Amaral, W.A., Ometto, A.R., 2020. Circular economy indicators for organizations considering sustainability and business models: Plastic, textile and electroelectronic cases. J. Clean. Prod. 247, 119137. https://doi.org/10.1016/j.jclepro.2019.119137

Saad, R., Koellner, T., Margni, M., 2013. Land use impacts on freshwater regulation, erosion regulation, and water purification: a spatial approach for a global scale level. Int. J. Life Cycle Assess. 18, 1253-1264. 
https://doi.org/10.1007/s11367-013-0577-1

Saidani, M., Yannou, B., Leroy, Y., Cluzel, F., Kendall, A., 2019. A taxonomy of circular economy indicators. J. Clean. Prod. 207, 542-559. https://doi.org/10.1016/J.JCLEPRO.2018.10.014

Scheepens, A.E., Vogtländer, J.G., Brezet, J.C., 2016. Two life cycle assessment (LCA) based methods to analyse and design complex (regional) circular economy systems. Case: making water tourism more sustainable. J. Clean. Prod. 114, 257-268. https://doi.org/10.1016/J.JCLEPRO.2015.05.075

Schipanski, M.E., Bennett, E.M., 2012. The Influence of Agricultural Trade and Livestock Production on the Global Phosphorus Cycle. Ecosystems 15, 256-268. https://doi.org/10.1007/s10021-011-9507-x

Schmidt, J.H., Weidema, B.P., Brandão, M., 2015. A framework for modelling indirect land use changes in Life Cycle Assessment. J. Clean. Prod. 99, 230-238. https://doi.org/10.1016/j.jclepro.2015.03.013

Searchinger, T., Heimlich, R., Houghton, R.A., Dong, F., Elobeid, A., Fabiosa, J., Tokgoz, S., Hayes, D., Yu, T.H., 2008. Use of U.S. croplands for biofuels increases greenhouse gases through emissions from land-use change. Science (80-. ). 319, 1238-1240. https://doi.org/10.1126/science.1151861

Shogren, R., Wood, D., Orts, W., Glenn, G., 2019. Plant-based materials and transitioning to a circular economy. Sustain. Prod. Consum. 19, 194-215. https://doi.org/10.1016/J.SPC.2019.04.007

Sikkema, R., Dallemand, J.F., Matos, C.T., van der Velde, M., San-Miguel-Ayanz, J., 2017. How can the ambitious goals for the EU's future bioeconomy be supported by sustainable and efficient wood sourcing practices? Scand. J. For. Res. https://doi.org/10.1080/02827581.2016.1240228

Sikkema, R., Junginger, M., McFarlane, P., Faaij, A., 2013. The GHG contribution of the cascaded use of harvested wood products in comparison with the use of wood for energy-A case study on available forest resources in Canada. Environ. Sci. Policy 31, 96-108. https://doi.org/10.1016/J.ENVSCI.2013.03.007

Sirkin, T., Houten, M. ten, 1994. The cascade chain: A theory and tool for achieving resource sustainability with applications for product design. Resour. Conserv. Recycl. 10, 213-276. https://doi.org/10.1016/09213449(94)90016-7

Skene, K.R., 2018. Circles, spirals, pyramids and cubes: Why the circular economy cannot work. Sustain. Sci. 13, 479-492. https://doi.org/10.1007/s11625-017-0443-3

Smil, V., 2011. Nitrogen cycle and world food production. World Agric. 2, 9-13.

Smol, M., Kulczycka, J., Avdiushchenko, A., 2017. Circular economy indicators in relation to eco-innovation in European regions. Clean Technol. Environ. Policy 19, 669-678. https://doi.org/10.1007/s10098-016-13238

Smolarski, N., 2012. High-value opportunities for Lignin: Unlocking its potential, Frost \& Sullivan. https://doi.org/10.1007/s00216-010-3562-6

Steffen, W., Richardson, K., Rockstrom, J., Cornell, S.E., Fetzer, I., Bennett, E.M., Biggs, R., Carpenter, S.R., de Vries, W., de Wit, C.A., Folke, C., Gerten, D., Heinke, J., Mace, G.M., Persson, L.M., Ramanathan, V., Reyers, B., Sorlin, S., 2015. Planetary boundaries: Guiding human development on a changing planet. Science (80. ). 347, 1259855-1259855. https://doi.org/10.1126/science.1259855

Su, B., Heshmati, A., Geng, Y., Yu, X., 2013. A review of the circular economy in China: Moving from rhetoric to implementation. J. Clean. Prod. 42, 215-227. https://doi.org/10.1016/j.jclepro.2012.11.020

Teigiserova, D.A., Hamelin, L., Thomsen, M., 2020. Towards transparent valorization of food surplus, waste and loss: Clarifying definitions, food waste hierarchy, and role in the circular economy. Sci. Total Environ. 706, 136033. https://doi.org/10.1016/j.scitotenv.2019.136033

Teigiserova, D.A., Hamelin, L., Thomsen, M., 2019. Review of high-value food waste and food residues biorefineries with focus on unavoidable wastes from processing. Resour. Conserv. Recycl. 149, 413-426. https://doi.org/10.1016/j.resconrec.2019.05.003

The Cradle to Cradle Products Innovation Institute, 2014. C2C Impact study technical report.

Thomsen, M., Faber, J.H., Sorensen, P.B., 2012. Soil ecosystem health and services - Evaluation of ecological indicators susceptible to chemical stressors. Ecol. Indic. 16, 67-75. https://doi.org/10.1016/j.ecolind.2011.05.012

Thomsen, M., Zhang, X., 2020. Life cycle assessment of macroalgal ecoindustrial systems, in: Sustainable Seaweed Technologies. Elsevier, pp. 663-707. https://doi.org/10.1016/b978-0-12-817943-7.00023-8

U.S. Chamber of Commerce Foundation, n.d. Measuring Circular Economy [WWW Document]. URL https://www.uschamberfoundation.org/circular-economy-toolbox/about-circularity/measuring-circulareconomy (accessed 5.22.19).

UNEP, 2019. Assessing Global Landuse: Balancing Consumption With Sustainable Supply.

UNFCCC, 2012. Report of the Conference of the Parties Serving as the Meeting of the Parties to the Kyoto Protocol on its Seventh Session, Held in Durban from 28 November to 11 December 2011 (2012) [WWW Document]. Paragraph. URL http://unfccc.int/resource/docs/2011/cmp7/eng/10a01.pdf (accessed 
Van Schaik, A., Reuter, M.A., 2016. Recycling Indices Visualizing the Performance of the Circular Economy. World Metall. - ERZMETALL 69, 4.

Wagendorp, T., Gulinck, H., Coppin, P., Muys, B., 2006. Land use impact evaluation in life cycle assessment based on ecosystem thermodynamics. Energy 31, 112-125. https://doi.org/10.1016/j.energy.2005.01.002

Wen, Z., Meng, X., 2015. Quantitative assessment of industrial symbiosis for the promotion of circular economy: a case study of the printed circuit boards industry in China's Suzhou New District. J. Clean. Prod. 90, 211219. https://doi.org/10.1016/J.JCLEPRO.2014.03.041

Woods, J.S., Veltman, K., Huijbregts, M.A.J., Verones, F., Hertwich, E.G., 2016. Towards a meaningful assessment of marine ecological impacts in life cycle assessment (LCA). Environ. Int. https://doi.org/10.1016/j.envint.2015.12.033

Worm, B., Barbier, E.B., Beaumont, N., Duffy, J.E., Folke, C., Halpern, B.S., Jackson, J.B.C., Lotze, H.K., Micheli, F., Palumbi, S.R., Sala, E., Selkoe, K.A., Stachowicz, J.J., Watson, R., 2006. Impacts of biodiversity loss on ocean ecosystem services. Science (80-. ). 314, 787-790. https://doi.org/10.1126/science.1132294

Yang, Q., Gao, Q., Chen, M., 2011. Study and integrative evaluation on the development of circular economy of Shaanxi Province, in: Energy Procedia. Elsevier, pp. 1568-1578. https://doi.org/10.1016/j.egypro.2011.03.268

Zhou, Z., Chen, X., Xiao, X., 2013. On Evaluation Model of Circular Economy for Iron and Steel Enterprise Based on Support Vector Machines with Heuristic Algorithm for Tuning Hyper-parameters. Appl. Math. Inf. Sci 7, 2215-2223. https://doi.org/10.12785/amis/070611 